PONTIFÍCIA UNIVERSIDADE CATÓLICA DO RIO DE JANEIRO

\title{
Economia Circular e a Gestão da Responsabilidade Socioambiental: um estudo sobre a Stone Pagamentos S.A.
}

\author{
Isabelle Vieira Nantes
}

Trabalho de Conclusão de CuRso

Centro de ciências socials - CCS

DEPARTAMENTO DE ADMINISTRAÇÃO

Graduação em Administração de Empresas 
Isabelle Vieira Nantes

Economia Circular e a Gestão da Responsabilidade Socioambiental: um estudo sobre a Stone Pagamentos S.A.

Trabalho de Conclusão de Curso, apresentado ao programa de graduação em Administração da PUC-Rio como requisito parcial para a obtenção do titulo de graduação em Administração.

Orientador(a): Ciro Torres

Rio de Janeiro Junho de 2021. 


\section{Agradecimentos}

Agradeço imensamente a toda a minha família, em especial aos meus pais, Christiane e Roberto, por toda a dedicação sem fim, toda a força e confiança dada durante o longo período em que estive na faculdade, tanto no curso de engenharia de produção, quanto agora, no de administração. Não posso deixar de agradecer ao meu maior parceiro dessa vida, meu irmão, Philippe, por todo amor e cumplicidade que sem dúvidas, foram fundamentais nessa minha trajetória.

Agradeço à Julia, por todo companheirismo, parceria, apoio e por estar sempre presente em incontáveis momentos de força, motivação e alegria. Esse apoio foi fundamental para conseguir superar momentos de ansiedade e insegurança.

Agradeço ao meu orientador, Ciro, por todos os ensinamentos e aprendizados que puderam ser absorvidos em toda elaboração deste estudo. Enorme gratidão. 


\section{Resumo}

Nantes, Isabelle Vieira. Economia Circular e a Gestão da Responsabilidade Socioambiental: um estudo sobre a Stone Pagamentos S.A. Rio de Janeiro, 2021. 50 p. Trabalho de Conclusão de Curso - Departamento de Administração. Pontifícia Universidade Católica do Rio de Janeiro.

Este trabalho tem como objetivo apresentar conceitos e fundamentos da economia circular, da responsabilidade socioambiental e da gestão de ações sustentáveis através de um estudo sobre a empresa Stone Pagamentos S.A. Para tal, foi realizado um levantamento bibliográfico sobre os temas, que poderão ser identificados nas práticas adotadas pela empresa através de análises críticas de dados e informações coletadas de fontes primárias e secundárias. Pode-se inferir a importância da responsabilidade socioambiental para as organizações e que ações voltadas para a sustentabilidade não são sentenças de que empresas não terão bom desempenho financeiro. Por fim, busca-se um olhar sobre como os conceitos podem transformar de forma mais eficiente o caminho para o desenvolvimento sustentável.

\section{Palavras-chave}

Economia circular, Responsabilidade Socioambiental, Sustentabilidade, Desenvolvimento Sustentável, Stone. 


\section{Abstract}

Nantes, Isabelle Vieira. Circular Economy and Environmental Responsibility Management: a study on Stone Pagamentos S.A. Rio de Janeiro, 2021. 50 p. Graduation Work - Administration Department. Pontifícia Universidade Católica do Rio de Janeiro.

This work aims to present concepts and fundamentals of the circular economy, corporate social responsibility and the management of sustainable actions through a study on the company Stone Payments AS. To this end, a bibliographical survey was carried out on the themes, which can be identified in the practices adopted by the company through critical analysis of data and information collected from primary and secondary sources. It can be inferred the importance of socio-environmental responsibility for organizations and that actions aimed at sustainability are not statements that companies will not have good financial performance. Finally, it seeks a look at how concepts can more efficiently transform the path to sustainable development.

Key-words

Circular Economy, Environmental Responsibility Management, Sustainability Management, Sustainability, Sustainable Development, Stone. 


\section{Sumário}

1. Introdução 1

1.1. Objetivo Final 3

1.2. Delimitação do Estudo 3

1.3. Relevância do Estudo 4

2. Referencial Teórico 5

2.1. Responsabilidade Social Empresarial 5

2.1.1. GRI - Global Reporting Initiative 7

2.1.2. ISO 14000

2.2. Sustentabilidade 9

2.2.1. Desenvolvimento Sustentável 12

2.2.2. Objetivos do Desenvolvimento Sustentável 13

2.3. Gestão Ambiental 15

2.3.1. Protocolo de Quioto 15

2.3.2. Créditos de Carbono 16

2.4. Operação Mais Limpa 19

2.5. Economia Circular 22

2.5.1. Logística Reversa 26

3. Metodologia 28

4. Histórico da Empresa 30

4.1. A Stone 30

4.2. A logística Stone 34

5. Apresentação e análise 37

5.1. Recuperação de Terminais 37

5.2. Outros Projetos Iniciais 39

5.2.1. Relatório de Sustentabilidade 39

5.2.2. Uso de Bicicletas elétricas 40 
5.2.2.1. Projeto Piloto na Stone

6 . Conclusões e Sugestões

Referências Bibliográficas 


\section{Lista de Figuras}

Figura 1 - Tripé da Sustentabilidade ..................................................... 10

Figura 2 - Base do Modelo PEPSE........................................................ 11

Figura 3 - 17 Objetivos de Desenvolvimento Sustentável............................... 14

Figura 4 - Princípios hierárquicos da P+L - o que fazer com os resíduos? ........ 20

Figura 5 - Elos da Economia Circular ........................................................ 23

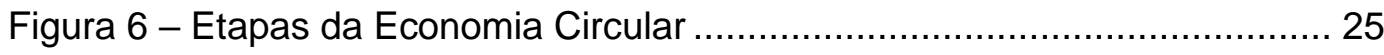

Figura 7 - Além da Maquininha ............................................................... 33

Figura 8 - Tuk-Tuks elétricos ........................................................ 44

\section{Lista de Tabelas}

Tabela 1: Equivalência entre o CO2 e demais Gases do Efeito Estufa. 


\section{Introdução}

O presente estudo, ainda que seja um trabalho de conclusão de curso, de certa forma, se tornou inédito, por se tratar de um tema o qual ainda não há evidências de outra pesquisa voltada para a empresa Stone e que fale de suas atividades direcionadas para a gestão da sustentabilidade, sobre em como aplicam a economia circular e a gestão da responsabilidade socioambiental.

As preocupações com a preservação ambiental não são novidade, há bastante tempo é debate em diversas mesas ao redor do globo. Com o crescimento populacional, revolução industrial, consumo exacerbado das matérias primas e poluição, muitos problemas ambientais estão se agravando, de tal modo que alguns são irreversíveis. Ao longo das últimas décadas, o conflito entre o crescimento econômico, a preservação ambiental e a degradação de recursos naturais estiveram em pauta e foram alvo de preocupações (NASCIMENTO,2012).

Segundo Jacobi (2003), como a maior parte da população brasileira vive em cidades, pode-se observar uma crescente degradação das condições de vida, refletindo diretamente em uma crise ambiental. A partir disso, é necessária uma reflexão sobre os desafios para mudar as formas de agir e de pensar sobre a questão ambiental (JACOBI, 2003).

A ideia de que os recursos são infinitos, abundantes e sempre disponíveis, independentemente de como são produzidos, sem ter preocupação com os desperdícios gerados ou com os componentes dos produtos no fim do ciclo de vida, trouxe uma série de impactos. Desde a Revolução Industrial, e muito especialmente desde o final da $2^{a}$ Guerra Mundial, este modelo tem conduzido à contínua delapidação dos recursos e ao crescente aumento de resíduo (LEITAO, 2015).

De acordo com Leitão (2015, p.152), desde a conferência rio-92, a questão envolvendo a "problemática do desenvolvimento sustentável tem ecoado 
globalmente com discussões sobre novas abordagens com vista à limitação do uso de recursos, novas formas de produzir, utilizar e descartar produtos que sejam menos poluentes e prejudiciais ao meio ambiente."

Atualmente, algumas alternativas são apresentadas como forma de minimização desses impactos, a economia circular é um exemplo. As novas formas de pensar das cadeias produtivas trazem benefícios estratégicos e operacionais, em ambos os níveis da economia, tanto no micro quanto no macro, incalculáveis oportunidades de inovação, de melhoria nos processos e modelos de negócios, criação de empregos e estimula o crescimento econômico inteligente, sustentável e integrador (LEITAO, 2015).

Nascimento (2012, p.110) aborda dentro do tema de operação mais limpa que o "aspecto mais importante é que a mesma requer não somente a melhoria tecnológica, mas a aplicação de know-how e a mudança de atitudes". Essa alternativa busca melhoria ininterrupta e assídua nos processos de negócios voltados para modelos mais sustentáveis.

As normas ISO 14000 determinam uma melhoria contínua nos Sistemas de Gestão Ambiental (SGA) para que estejam de acordo com todas as políticas e leis ambientais. Não tem como objetivo tornar uma empresa verde, mas sim, propõe que ela minimize os danos causados ao meio ambiente. Com isso, traz efeitos muito positivos para a saúde econômica, ecológica e social, reafirmando que é possível atingir o crescimento econômico sendo responsável com o meio ambiente.

Para as empresas, existe uma cobrança por parte da população em serem responsáveis no âmbito social e ambiental. O conceito de responsabilidade social empresarial pode ser atrelado ao fato de que uma organização é responsável pelos impactos e pelas ações gerenciais que produzem, tanto no ambiente interno quando externo (SIMOES et al., 2008).

Seu exercício é a gestão dos negócios não restrita apenas ao resultado econômico da atividade produtiva, mas à contínua aprendizagem, inovação e recombinações institucionais, subsidiadas nas práticas de gestão, na vontade política interna - portanto, com grande importância para o papel de suas lideranças -, na qualificação, capacitação e conhecimento das ferramentas e técnicas associadas. (SIMOES et al., 2008, p.21). 
No livro que conta história da empresa Stone Pagamentos S.A., os autores Lins e Bourroul (2021, p.81) ressaltam que "reunimos empreendedores não executivos - que priorizam o coletivo, conscientes de que, quando o negócio vai bem, todos prosperam", além disso, diz que "fazer diferente do que manda o status requer muita energia e produtividade".

Essa pesquisa tem como objetivo mostrar a importância de mudanças internas visando a gestão adequada da sustentabilidade e de práticas mais limpas na cadeia produtiva da empresa. Para isso, a Stone adequou seu processo de recuperação de terminais à economia circular e logística reversa, bem como a utilização de bicicletas elétricas em algumas cadeias da logística.

\subsection{Objetivo Final}

Este trabalho pretende analisar, descrever e destacar a importância da Responsabilidade Socioambiental e da Economia Circular, a partir do estudo da fintech brasileira Stone Pagamentos S.A.

Como a pressão para que as empresas tomem cada vez mais iniciativa frente ao problema de poluição, degradação ambiental e as diversas práticas que são prejudiciais ao meio ambiente, se torna essencial a discussão sobre alguns fatores necessários para que uma empresa seja considerada responsável.

Por meio da abordagem teórica empírica, este estudo busca compreender as possíveis práticas de sustentabilidade as quais a empresa já vem se aprofundando, como a larga operação que envolve a recuperação de terminais inativos, contando com uma logística reversa para a reutilização dessas máquinas e o uso de bicicletas elétricas integradas ao processo logístico.

\subsection{Delimitação do Estudo}

Este estudo visa mais especificamente abordar a questão e uma melhor compreensão sobre a gestão da sustentabilidade, responsabilidade social empresarial e Economia Circular com foco na empresa Stone Pagamentos S.A e em suas práticas. Tal ângulo de análise se mostra interessante e importante 
pois, com o crescimento populacional e a degradação ao meio ambiente acontecendo de forma desmedida, é necessário que tanto as empresas quanto o governo busquem alternativas que minimizem o problema.

O conceito de Economia Circular vem se tornando cada vez mais necessário e importante para que sejam adotadas medidas visando a reforma e a reciclagem, dando cadência a circulação dos materiais não biodegradáveis. Outro ponto que será abordado é o quanto o uso de bicicletas elétricas pode contribuir para o desenvolvimento econômico e sustentável da empresa, além de trazer maior qualidade de vida para os seus funcionários.

\subsection{Relevância do Estudo}

Para o presente estudo, o objetivo é apresentar ações de sustentabilidade que estão sendo realizadas e/ou ainda serão, esclarecendo o papel da responsabilidade social empresarial, da gestão da sustentabilidade e da logística reversa a fim de promover iniciativas mais frequentes por parte das empresas. Além disso, gerar uma conscientização e transformação no modo de pensar, gerenciar e planejar os processos e operações, bem como influenciar o mercado como um todo.

Quanto aos resultados, poderão ser úteis para outras pesquisas acadêmicas, afinal podem gerar reflexão sobre o futuro e uma discussão sobre os novos caminhos para um desenvolvimento mais sustentável e uma gestão da sustentabilidade corporativa mais assertiva. 


\section{Referencial Teórico}

Neste tópico são apresentados e discutidos aspectos conceituais e estudos relacionados ao tema em investigação e que servirão de base para a análise realizada.

\subsection{Responsabilidade Social Empresarial}

A busca pela minimização ou solução de alguns problemas ambientais exige uma nova atitude por parte das empresas e dos administradores, é necessário passar a considerar o meio ambiente em suas decisões. Como existe a pressão da sociedade e medidas governamentais, as empresas acabam sentindo a obrigação de tomar iniciativas que promovam a qualidade e a preservação do meio ambiente.

Concomitantemente aos debates sobre a questão da responsabilidade social e da ética, cresce na comunidade de negócios a indagação sobre a conexão do desenvolvimento econômico das empresas e as suas práticas de responsabilidade social (MACHADO FILHO, 2006).

Machado Filho ressalta que "a evolução institucional ocorre também no sentido de que as pessoas estão mais conscientes dos seus direitos e deveres sociais, menos tolerantes a práticas abusivas e antiéticas" (MACHADO FILHO, 2006, p. 16).

De acordo com Simões (2008, p.21), o conceito de responsabilidade social empresarial pode ser associado ao exercício, por parte de uma organização, de gerir os negócios de forma não restrita apenas ao resultado econômico, mas à "contínua aprendizagem, inovação e recombinações institucionais, subsidiadas nas práticas de gestão, na vontade política interna" e "na qualificação, capacitação e conhecimento das ferramentas e técnicas associadas." 
ideia poderosa e objetiva: empresa sustentável é aquela que gera lucro para os acionistas, ao mesmo tempo em que protege o meio ambiente e melhora a vida das pessoas com que mantém interações. (SAVITZ; WEBER, 2007 apud BASSETTO, 2010, p.641)

Uma empresa sustentável é aquela que cria valor a longo prazo aos acionistas e também aos proprietários, além disso contribui para a solução de problemas ambientais e sociais. Os negócios ou empresas sustentáveis são as que:

- Atendem as necessidades atuais fazendo o uso de recursos de forma sustentável;

- Procuram manter o equilíbrio em relação às tecnologias limpas, reuso, reciclagem ou renovação de recursos;

- Restauração de danos;

- Buscam solucionar e ajudar em problemas sociais

- Geração de renda a fim de se manter.

(CROSBIE; KNIGHT, 1995 apud BARBIERI, 2007)

Foi lançado pela ONU, em 2005, os princípios para o Investimento Responsável, elaborados em conjunto com o PNUMA (Programa das Nações Unidas para o Ambiente) e o Global Compact. Seis são os princípios que foram baseados nas mais adequadas práticas de investimentos que tenham como foco as questões ambientais, sociais e de governança corporativa (BARBIERI, 2007).

Barbieri (2007) ressalta que uma outra pressão vem surgindo nos últimos anos, a pressão da sociedade, afinal houve um aumento da consciência da população em geral e principalmente daqueles consumidores que desejam e buscam cada vez mais utilizar produtos e serviços ambientalmente sustentáveis. É evidente o crescimento de rótulos e/ou selos verdes nas prateleiras de supermercados e lojas, o que traz um importante indicador de que a consciência ambiental está cada vez mais presente.

Para conquistar o caminho do desenvolvimento financeiro e na visão mercadológica, essas medidas que as empresas podem adotar com o intuito de preservar o meio ambiente, se torna uma vantagem competitiva e um ativo intangível. 


\subsubsection{GRI - Global Reporting Initiative}

O GRI (Global Reporting Initiative) foi criado em 1997 e surgiu de uma parceria entre a Ceres (Coalition for Environmentally Responsible Economies) e o Programa Ambiental das Nações Unidas. Nasceu com o intuito de dar suporte às empresas ensinando a ser mais transparentes e a reconhecer os impactos que produzem. Nascimento (2012) ressalta que o GRI busca orientar as organizações que estejam elaborando relatórios e a ajuda na articulação de suas contribuições em direção ao desenvolvimento sustentável.

São 11 princípios nos quais o GRI se baseia: transparência, inclusividade, auditabilidade, completude, exatidão, neutralidade, comparabilidade, clareza, conveniência, relevância e contexto de sustentabilidade. Essa ferramenta serve para desenvolver e disseminar os relatórios de sustentabilidade pelo mundo e definir as melhores diretrizes (SIMOES et al., 2008).

Por ser padronizado, permite uma facilidade na comparação da questão socioambiental entre as diversas organizações que o adotem, o que contribui fortemente para seus stakeholders (SIMOES et al., 2008). O GRI possui algumas diretrizes que fazem uso de indicadores distribuídos nas três esferas de sustentabilidade: econômica, ambiental e social (SIMOES et al., 2008). São exemplos desses indicadores:

- Econômicos: salários e benefícios, produtividade do trabalho, criação de empregos, despesas em pesquisa e desenvolvimento, investimentos em treinamento e outras formas de capital humano;

- Ambientais: impactos de processos, produtos e serviços no ar, na água, na terra, na biodiversidade e na saúde humana;

- Sociais: saúde e segurança no ambiente de trabalho, retenção de funcionários, direitos dos trabalhadores, direitos humanos, salários e condições de trabalho.

(SIMOES et al., 2008).

De acordo com Simões et al. (2008), um dos pontos que precisa ser destacado é o apoio de empresas e organizações não governamentais ao redor do mundo, obtendo a participação ativa de representantes da área de negócios, contabilidade, investimentos, meio ambiente, direitos humanos, pesquisas e organizações trabalhistas. Importante que as empresas tenham o controle de suas ações, pois caso não tenham atingido a expectativa dentro do prazo 
proposto, elas deverão dar explicações sobre o problema. Essa justificativa que as empresas precisam dar acabam gerando um comprometimento maior com o processo.

Simoes et al. (2008, p.139) destaca que "por não prever a verificação externa como meio de avaliação da consistência dos resultados produzidos, o GRI não garante a credibilidade das informações dos relatórios das empresas". Além disso, o GRI complementa o Pacto Global tentando transformar seus princípios em algo mensurável e aplicável para as empresas que o adotam, através de seus relatórios, permitindo que as partes externas possam acompanhar as empresas (SIMOES et al., 2008).

\subsubsection{ISO 14000}

A ISO (International Organization for Standardization) conta com mais de 130 países membros, com alguns países representados por entidades governamentais, que é o caso do Brasil, representado pela Associação Brasileira de Normas Técnicas (ABNT). Além disso, conta com 180 Comitês Técnicos (TCs), cada um sendo especializado por uma área de atuação. Nascimento (2012, p.101) define as normas como "normas internacionais que padronizam produtos e processos".

A série de normas ISO 14000 foi lançada em 1996 e "as organizações certificadas, e seus produtos e serviços, passam a ser reconhecidos internacionalmente, distinguindo-se daquelas organizações que somente atendem à legislação ambiental", e, "as normas da série ISO 14000 também estabelecem as diretrizes para as auditorias ambientais, avaliação de desempenho ambiental, rotulagem ambiental e análise do ciclo de vida dos produtos" (NASCIMENTO, 2012, p.103).

No Brasil a série mantém a numeração, no entanto são precedidas do designativo NBR da ABNT. Segundo Simões et al. (2008, p.171), a série ISO está entre os mais conhecidos padrões internacionais que regulamentam a questão da proteção ambiental e tem o intuito de:

- Tornar o processo mais eficiente, seguro e limpo;

- Facilitar as negociações entre os países; 
- Suprir os governos com dados e informações para a pesquisa nas áreas de saúde, segurança e legislação ambiental;

- Auxiliar na transferência de tecnologia para os países em desenvolvimento.

Nascimento (2012, p.107) evidencia que para conquistar a certificação ambiental, uma organização deve cumprir as seguintes exigências:

- Ter implantado um Sistema de Gestão Ambiental;

- Cumprir a legislação ambiental aplicável ao local da instalação; e

- Assumir um compromisso com a melhoria contínua de seu desempenho ambiental.

Logo, as normas se tornam importante para a devida proteção das organizações que respeitam as leis e os princípios de conservação ambiental, bem como para universalizar conceitos e procedimentos, sem perder de vista características e valores regionais (NASCIMENTO, 2012). No entanto, Nascimento (2012) conclui que as normas também podem ser utilizadas como uma vantagem competitiva, já que não é explicitado como a organização deve alcançar as metas, não há uma descrição de tipo de desempenho e não há uma determinação sobre os resultados a serem atingidos.

\subsection{Sustentabilidade}

Sustentabilidade vem do termo sustentável, que, por sua vez, deriva do latim sustentare, que significa sustentar, defender, favorecer, apoiar, conservar e/ou cuidar, manter, resistir (PAZ; KIPPER, 2016). A consciência ecológica mundial passou a ser despertada nos anos 60, com um grupo de cientistas que iniciaram o Clube de Roma. Nesse debate o grupo alertou, através de modelos matemáticos, sobre os riscos de um crescimento econômico contínuo, baseado em recursos naturais não renováveis (NASCIMENTO, 2012).

Alguns anos depois, em julho de 1972, foi realizada a Conferência das Nações Unidas sobre Meio Ambiente e Desenvolvimento, o qual contou com a presença de 113 países, 19 órgãos intergovernamentais e mais de 400 organizações não governamentais. "Pela primeira vez o meio ambiente estava sendo discutido pelos governos do mundo como um tema em si, problematizando a dependência entre desenvolvimento e meio ambiente" (SABBAGH, 2011, p.15). Após a conferência, visando um maior controle sobre 
os impactos ambientais, os países iniciaram uma estruturação de seus órgãos ambientais e definiram legislações (NASCIMENTO, 2012).

O conceito de sustentabilidade ganhou força a partir da Conferência Mundial de Desenvolvimento e Meio ambiente, realizada no Rio de Janeiro, em 1992. De acordo com Nascimento (2012), após a Rio-92, a sociedade em geral e as empresas em particular passaram a compreender a necessidade de implementar uma nova visão de desenvolvimento econômico, algo que pudesse garantir a produção de bens e serviços e, ao mesmo tempo, atender às necessidades básicas do ser humano e preservar o meio ambiente. Em síntese, tem-se que o conceito de desenvolvimento sustentável é composto por três importantes dimensões: a econômica, a social e a ambiental.

Figura 1 - Tripé da Sustentabilidade

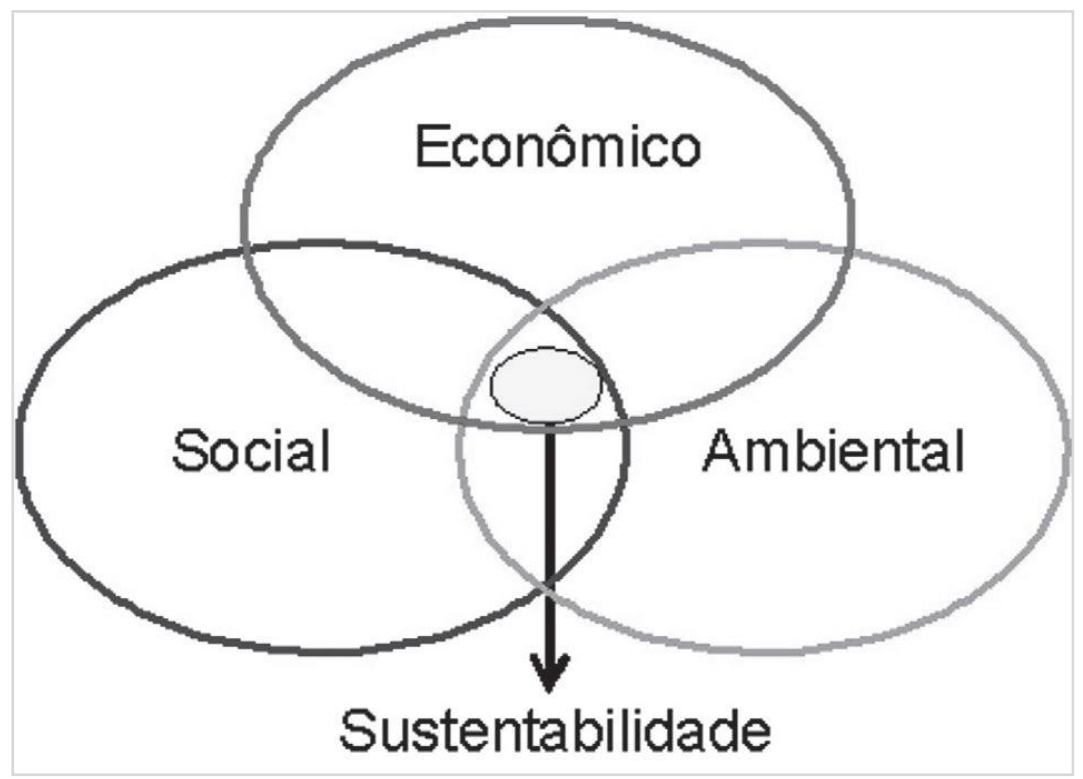

Fonte: Nascimento (2012, p.38)

Para que a sustentabilidade realmente aconteça, é necessária a interação entre as três dimensões. De acordo com Paz e Kipper (2016), é necessário ponderar sobre a necessidade das empresas se basearem neste tripé para tomarem as suas decisões, mantendo a sustentabilidade social, com atividades ligadas à população, sustentabilidade econômica ao precisar gerenciar de forma lucrativa e ainda assim manter a preocupação com os impactos ao meio ambiente. 
O conceito de uma empresa sustentável pode ser evidenciado como:

Uma empresa sustentável, por conseguinte, é aquela que contribui para o desenvolvimento sustentável ao gerar, simultaneamente, benefícios econômicos, sociais e ambientais - conhecidos como os três pilares do desenvolvimento sustentável. (Hart \& Milstein, 2004, p.66)

Coral (2002), define um modelo de Planejamento Estratégico para a Sustentabilidade Empresarial - PEPSE, que tem 0 intuito de oferecer as empresas ferramentas de planejamento as quais a possibilite analisar a sua posição em relação às variáveis de sustentabilidade, a fim de prepará-las para atuar em mercados futuros e estabelecendo prioridades para o desenvolvimento sustentável.

Figura 2 - Base do Modelo PEPSE

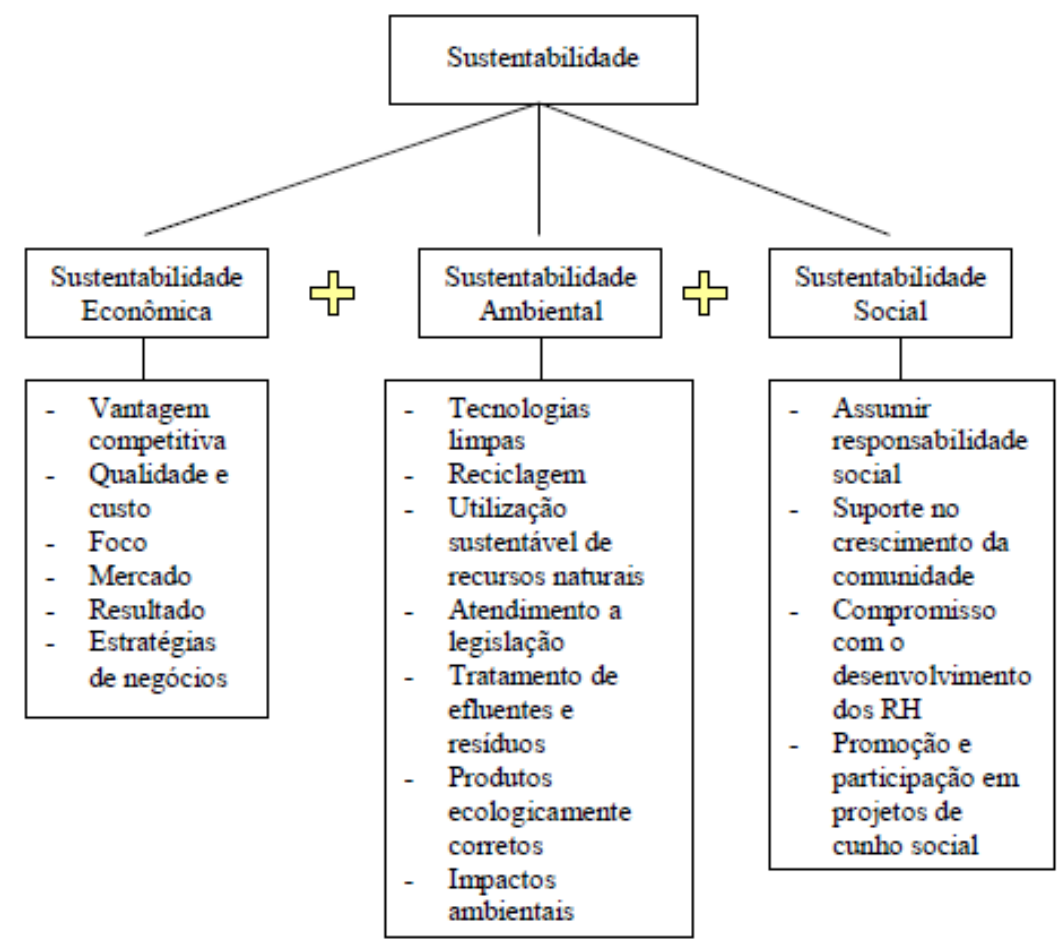

Fonte: Coral (2002, p.129)

Conforme Coral (2002), dentro dos princípios de sustentabilidade, não devemos separar as questões sociais das questões ambientais. Dito isso, quando uma organização é ecologicamente sustentável, consequentemente ela estará atuando de forma socialmente responsável, de maneira que atinja os 
interesses de seus empresários e também todos os stakeholders (CORAL, 2002).

Portanto, de acordo com Coral (2002, p.46), "uma vez que a questão do crescimento econômico está presente na competitividade" podemos concluir que "a sustentabilidade de uma empresa dependerá de sua competitividade, da sua relação com o meio ambiente natural e da sua responsabilidade social".

\subsubsection{Desenvolvimento Sustentável}

Em 1983, o Secretário-Geral da ONU convidou a médica Gro Harlem Brundtland, mestre em saúde pública e ex primeira-Ministra da Noruega, para estabelecer e presidir a Comissão Mundial sobre o Meio Ambiente e Desenvolvimento, nele, foi relatado que o desenvolvimento sustentável não possui limites, mas possui limitações as quais são impostas pela sociedade e pelas tecnologias atuais, no que tange aos recursos ambientais e naturais, e pela própria capacidade da biosfera de conseguir absorver os efeitos das atividades humanas.

Segundo (NASCIMENTO, 2012, p.36), e com base no Relatório Brundtland, o qual tentou considerar os dois lados da questão relativa ao desenvolvimento econômico, as bases são:

- Sistema político que assegure a efetiva participação dos cidadãos no processo decisório;

- Sistema econômico capaz de gerar excedentes e knowhow técnico em bases confiáveis e constantes;

- Sistema social que possa resolver as tensões causadas por um desenvolvimento não equilibrado;

- Sistema de produção que preserve a base ecológica do desenvolvimento;

- Sistema tecnológico que busque constantemente novas soluções;

- Sistema internacional que estimule padrões sustentáveis de comércio e financiamento;

- Sistema administrativo flexível e capaz de se autocorrigir.

O conceito de Desenvolvimento Sustentável, com base no Relatório Brundtland e de acordo com Nascimento (2012, p.36) "não diz respeito apenas ao impacto da atividade econômica no meio ambiente, mas refere-se, 
principalmente, às consequências dessa relação na qualidade de vida e no bemestar da sociedade, tanto a presente quanto a futura".

Segundo o Relatório Brundtland, algumas medidas devem ser tomadas pelos Estados nacionais:

- Limitação do crescimento populacional;

- Garantia de alimentação em longo prazo;

- Preservação da biodiversidade e dos ecossistemas;

- Diminuição do consumo de energia e desenvolvimento de tecnologias que admitem o uso de fontes energéticas renováveis;

- Aumento da produção industrial à base de tecnologias ecologicamente adaptadas nos países não industrializados;

- Controle da urbanização selvagem e integração entre campo e cidades menores; e

- Satisfação das necessidades básicas.

Internacionalmente, as metas propostas pelo Relatório são:

- As organizações devem adotar a estratégia de desenvolvimento sustentável;

- A comunidade internacional deve proteger os ecossistemas supranacionais como a Antártica, os oceanos e o espaço;

- As guerras devem ser banidas; e

- A ONU deve implementar um programa de Desenvolvimento Sustentável.

(NASCIMENTO, 2012, p.38)

O relatório Brundtland conclui que o desenvolvimento sustentável é um processo de mudança no qual a exploração dos recursos, a orientação dos investimentos, os rumos do desenvolvimento tecnológico e a mudança institucional devem estar de acordo com as necessidades atuais e futuras. (NOSSO FUTURO COMUM, 1991).

\subsubsection{Objetivos do Desenvolvimento Sustentável}

O secretário das Nações Unidas, Kofi Annan, em 2000, lançou o Pacto Global, que pode ser considerado como um chamado para as empresas alinharem as suas estratégias e operações baseados em princípios universais nas áreas de Direitos Humanos, Trabalho, Meio Ambiente e Anticorrupção (Rede Brasil do Pacto Global, 2019).

No ano de 2015, a ONU propôs aos seus países membros uma agenda de desenvolvimento sustentável com duração para os próximos 15 anos, chamada 
Agenda 2030, composta por 17 Objetivos de Desenvolvimento Sustentável (ODS).

Os ODS buscam assegurar os direitos humanos, acabar com a pobreza, lutar contra a desigualdade e a injustiça, alcançar a igualdade de gênero e o empoderamento de mulheres e meninas, agir contra as mudanças climáticas, bem como enfrentar outros dos maiores desafios de nossos tempos. 0 setor privado tem um papel essencial nesse processo como grande detentor do poder econômico, propulsor de inovações e tecnologias e influenciador e engajador dos mais diversos públicos - governos, fornecedores, colaboradores e consumidores (Rede Brasil do Pacto Global, 2019).

Figura 3 - 17 Objetivos de Desenvolvimento Sustentável

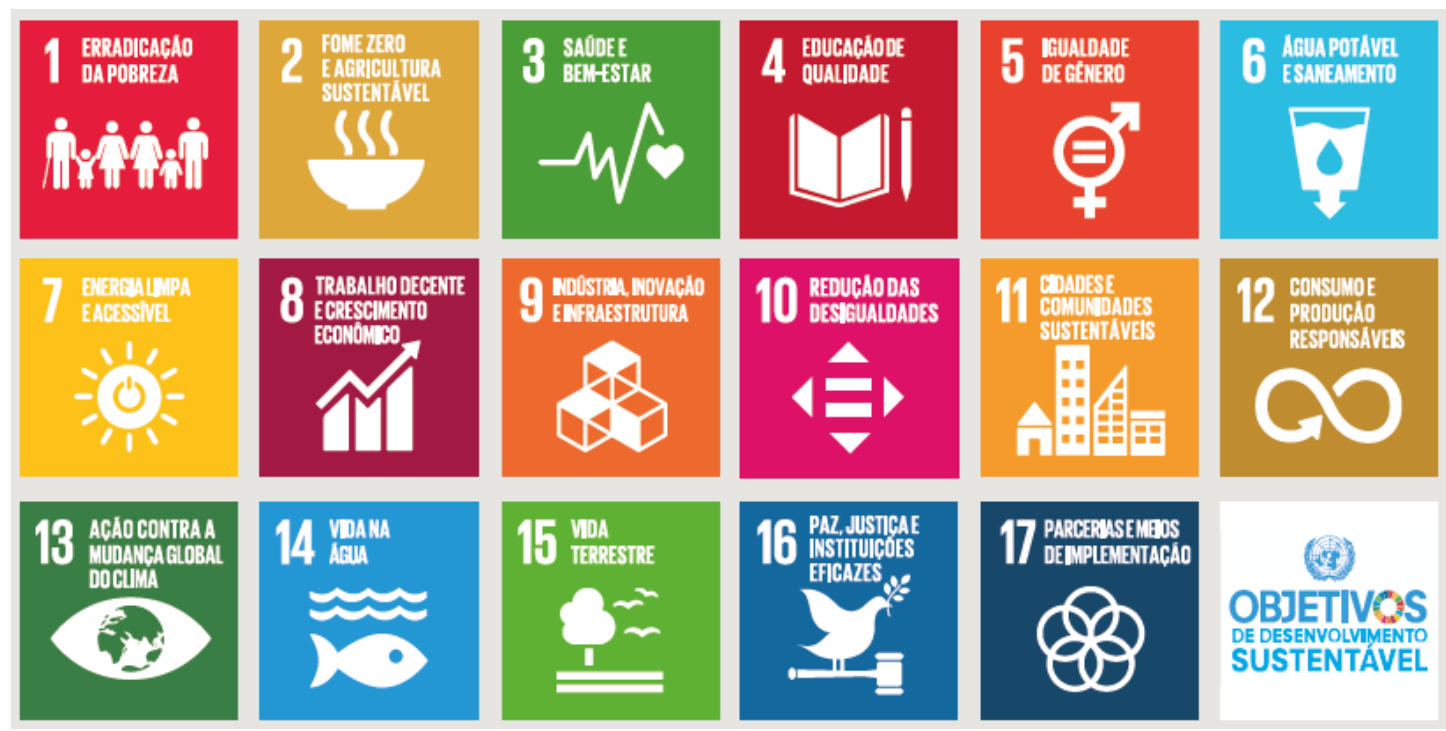

Fonte: Rede Brasil do Pacto Global, 2019.

Como forma de centralizar as ações, foi criado o GT ODS, que possuiu as seguintes prioridades para o ano de 2019:

- Contribuição do setor empresarial para o alcance dos ODS no Brasil;

- Implementação e reporte com foco nos ODS;

- Integração dos ODS na estratégia empresarial;

- Financiamento da Agenda 2030 com novos investidores.

(Rede Brasil do Pacto Global, 2019) 


\subsection{Gestão Ambiental}

A gestão ambiental pode ser entendida como um conjunto de diretrizes e atividades administrativas e operacionais, que com o planejamento, direção, controle, alocação de recursos, tem o objetivo de obter efeitos positivos sobre 0 meio ambiente, podendo obter uma redução ou até eliminação dos danos e problemas causados pelas ações humanas (BARBIERI, 2007).

Essas ações para combater a poluição começaram efetivamente após a Revolução Industrial, e, segundo Barbieri (2007), o crescimento da consciência ambiental por amplos setores da sociedade é um fato totalmente indutor da emergência da gestão ambiental.

Nota-se, ao longo dos últimos tempos, um avanço muito significativo no ideal do movimento ambientalista, com a incorporação de novos conceitos, novas atividades e novos valores. Com o amadurecimento do movimento, todos começam a caminhar para uma nova direção que busca resultados efetivos de preservação.

\subsubsection{Protocolo de Quioto}

Na rio-92 foi discutida a necessidade de medidas que garantissem a redução de $\mathrm{CO} 2$, e já era identificado como sendo um dos principais responsáveis pelo efeito estufa. Em 1997 foi firmado o Protocolo de Quioto, na cidade de Quioto, no Japão, porém entrou em vigor, de fato, somente em fevereiro de 2005. O principal objetivo era estabelecer algumas metas e ações para que os países envolvidos reduzissem as suas emissões do gás. Segundo Nascimento (2012, p.26), "entre 2008 e 2012, à meta era de 5,2\%, tendo como base os níveis de emissão de 1990". O protocolo instituiu três mecanismos de flexibilização para que a meta fosse atingida, são eles:

- Emissions Trade (comércio de emissões) - são utilizados entre países industrializados - constantes do Anexo I do Protocolo e aqui neste livro apresentados no Quadro 1. Através desse mecanismo, um país que tenha reduzido suas emissões acima de sua meta, pode transferir o excesso de suas reduções para outro país que não tenha alcançado tal condição.

- Joint Implementation (implementação conjunta) - é outro "mecanismo flexível" que os países do Anexo I podem fazer uso para reduzir suas emissões sem tomar medidas 
no próprio país. O mecanismo possibilita a cada um destes países realizar projeto de redução de gases do efeito estufa em outro país do Anexo 1, contabilizando, a seu favor, as emissões reduzidas.

- Mecanismo de Desenvolvimento Limpo (MDL)* - O CDM (Clean Development Mechanism), traduzido para MDL, tem como objetivo a diminuição da emissão dos gases causadores do efeito estufa, criando um mecanismo através do qual as partes não incluídas no Anexo I, enquanto buscam alcançar o desenvolvimento sustentável, auxiliam os integrantes do Anexo I no cumprimento de suas metas de limitação de emissões, de modo que seja atingido o objetivo do Protocolo.

(NASCIMENTO, 2012, p.26)

Segundo Nascimento (2012, p.27), a intenção do Protocolo de Quioto é a de que "aqueles países responsáveis pelas maiores emissões de $\mathrm{CO} 2$ possam, enquanto não conseguem diminuir suas próprias emissões, investir capitais na produção de sistemas agrícolas fixadores de carbono da atmosfera, em países que tenham potencial para isso".

O protocolo estimula os países que assinaram a cooperarem entre si, através de algumas ações:

- Reformar os setores de energia e transportes;

- Promover o uso de fontes energéticas renováveis;

- Eliminar mecanismos financeiros e de mercado inapropriados aos fins da Convenção;

- Limitar as emissões de metano no gerenciamento de resíduos e dos sistemas energéticos; e

- Proteger florestas e outros sumidouros de CO2.

(NASCIMENTO, 2012, p.27)

O Brasil não faz parte do Anexo 1, pelo motivo de que as suas emissões são mais recentes, no país as principais emissões são de desmatamentos e queimadas, os quais representam $75 \%$, já a queima de combustíveis fósseis representa $22 \%$ do total (NASCIMENTO, 2012).

\subsubsection{Créditos de Carbono}

Vários gases são responsáveis pelo aquecimento global, no entanto, o principal causador do efeito estufa é o dióxido de carbono (CO2), que podemos também chamar de gás carbônico. "O CO2 é emitido principalmente pela queima de combustíveis fósseis, como o carvão, o petróleo e derivados (gasolina e diesel) e gás natural." (SABBAGH, 2011, p.96). 
Segundo Sabbagh (2011), o combate ao aquecimento global precisa ser urgente, pois o sistema climático da terra se retroalimenta, ou seja, quanto mais efeito estufa, maior é o risco e maior são as consequências, que aparecem a médio e longo prazo. Como alguns ecossistemas não se recompõem, a situação fica ainda mais complicada, por esse motivo é necessário compreender as causas e atacá-las de forma a reduzir as emissões dos gases do efeito estufa.

\begin{abstract}
Para mitigação são necessárias ações como evitar o desmatamento e as queimadas; reduzir o consumo de combustíveis derivados do petróleo; incentivar o uso de energias limpas e renováveis (como os biocombustíveis e as energias solar e eólica); incentivar a eficiência energética e a economia de recursos (como, por exemplo, os transportes públicos e os não motorizados). (SABBAGH,2011, p.96)
\end{abstract}

A queima de combustíveis fósseis está inclusa entre as principais fontes geradoras de $\mathrm{CO} 2$, mas não se pode deixar para trás as inúmeras queimadas de florestas e de resíduos. O CO2 pode ficar por décadas na atmosfera e por isso os seus efeitos ocorrem a longo prazo, no entanto, hoje em dia já conseguimos perceber o tanto que essas emissões causam de malefícios para a natureza e o meio ambiente. De acordo com Barbieri (2007), diversos são os problemas decorrentes do aumento de temperatura, entre eles:

- Mudanças nos regimes de chuvas.

- Aumento da frequência de turbulências climáticas como furacões e maremotos.

- Elevação do nível dos oceanos pelo derretimento das geleiras.

- Redução de espaços, de áreas agricultáveis.

- Entre outros.

O CO2 serve como base para que outros gases sejam calculados a fim de medir as quantidades de gases causadores do efeito estufa. Esses gases são quantificados de acordo com o seu potencial de aquecimento global em relação ao dióxido de carbono (NASCIMENTO, 2012). Por este motivo os créditos de carbono são cotados por tonelada de dióxido de carbono-equivalente (CO2e) e a relação é demonstrada na tabela abaixo. 
Tabela 1: Equivalência entre o CO2 e demais Gases do Efeito Estufa

\begin{tabular}{|l|c|}
\hline \multicolumn{1}{|c|}{ Gases de Efeito Estufa } & Créditos de Carbono (por tonelada) \\
\hline CO2 - Dióxido de carbono & 1 \\
\hline CH4 - Metano & 21 \\
\hline N2O - Óxido Nitroso & 310 \\
\hline HFCs - Hidrofluocarbonetos & $140 \sim 11700$ \\
\hline PFCs - Perfluocarbonetos & $6500 \sim 9200$ \\
\hline SF6 - Hexafluoreto de Enxofre & 23900 \\
\hline
\end{tabular}

Fonte: Iniciativa Verde (2009) apud Nascimento (2012, p. 30)

"As empresas poluidoras compra em bolsa, ou diretamente das organizações empreendedoras, as toneladas de carbono, sequestradas ou não emitidas, através de um bônus chamado Certificado de Redução de Emissões (CER)" diz Nascimento (2012, p.31).

Algumas empresas são especializadas em projetos de vendas dos créditos de carbono no mercado global, além disso, há também selos oferecidos dependendo da identificação pública de produtos, serviços, ações, instalações, eventos, etc para que tenham os seus volumes de carbono neutralizados (NASCIMENTO, 2012). Para o devido recebimento desses selos, é necessário que as instituições busquem absorver a quantidade de CO2 gerada.

De todo modo, existe uma cobrança em relação as emissões se espalhando, com isso, é necessário que as empresas calculem o custo desse impacto. Essa ação pode atrair investidores em ações e títulos de dívida, bem como para a exportação (ÉPOCA NEGÓCIOS, 2021).

\footnotetext{
A Natura, de 2007 a 2018, compensou 3,6 milhões de toneladas de gases, gerando $R \$ 1,6$ bilhão. Em 2019, investiu $R \$ 33,5$ milhões nas comunidades impactadas, incluindo 38 projetos que geraram créditos de carbono. Nos processos internos, investe em materiais de menor impacto, e os projetos de produtos incluem as emissões nos custos, diz a diretora global de Sustentabilidade da Natura \& Co., Denise Hills (ÉPOCA NEGÓCIOS, 2021).
}

Vale destacar que para empresas que possuem emissões exageradas de carbono, um adiantamento na taxação ajuda a controlar e a tomar atitudes mais assertivas de prevenção, ajudando a incentivar o uso de matérias primas menos poluentes, operações mais limpas e processos mais sustentáveis. 


\subsection{Operação Mais Limpa}

Esse modelo de produção vem sendo desenvolvido pelo PNUMA (Programa das Nações Unidas para o Meio Ambiente) e pela Organização das Nações Unidas para o Desenvolvimento Industrial (ONUDI) desde a década de 1980, com o foco de instrumentalizar os conceitos e objetivos do desenvolvimento sustentável (BARBIERI, 2007). De acordo com Nascimento (2012), a operação mais limpa ou produção mais limpa $(P+L)$, pode ser definida como ajustes no processo produtivo que permitem a redução/geração de vários resíduos e como método de prevenção, poderiam ser feitas tanto pequenas reparações quanto a aquisição de novas tecnologias - simples e/ou complexas.

A produção mais limpa tende a adotar uma abordagem preventiva e em relação aos processos produtivos, direciona o seu foco para matéria prima e energia, com a eliminação de materiais tóxicos e a redução nas quantidades e toxidade dos resíduos e emissões (NASCIMENTO, 2012).

\footnotetext{
Pela definição do Programa das Nações Unidas para o Meio Ambiente de 1994, a P+L é a melhoria contínua dos processos industriais, produtos e serviços, visando:

- Reduzir o uso de recursos naturais;

- Prevenir na fonte a poluição do ar, da água, e do solo; e

- Reduzir a geração de resíduos na fonte, visando reduzir os riscos aos seres humanos e ao ambiente natural.
}

(NASCIMENTO, 2012, p.11)

De acordo com Barbieri (2007, p.135), o PNUMA adverte sobre a existência de outras expressões, similares à $P+L$, "como tecnologia limpa, redução de desperdícios, ecoeficiência, prevenção da poluição, para as quais não já consenso universal". Quanto as propostas similares, a PNUMA diz: "reconhecemos que a $\mathrm{P}+\mathrm{L}$ e outras estratégias preventivas, como a ecoeficiência, produtividade ambiental e prevenção da poluição são opções preferíveis" e por essa declaração a $\mathrm{P}+\mathrm{L}$ deve ser entendida como "a aplicação contínua de uma estratégia preventiva integrada envolvendo processos, produtos e serviços a fim de alcançar benefícios econômicos e sociais, para a saúde humana e o meio ambiente" (BARBIERI, 2007, p.136).

As organizações signatárias dessa Declaração se comprometem a usar sua influência para encorajar a adoção 
de práticas de produção e consumo sustentáveis nas suas relações com os stakeholders. Ao fazer isso, essas organizações estariam participando, portanto, de uma espécie de acordo voluntário unilateral coletivo (BARBIERI, 2007, p.136).

Produção mais limpa trabalha conforme a seguinte hierarquia.

Figura 4 - Princípios hierárquicos da P+L - o que fazer com os resíduos?

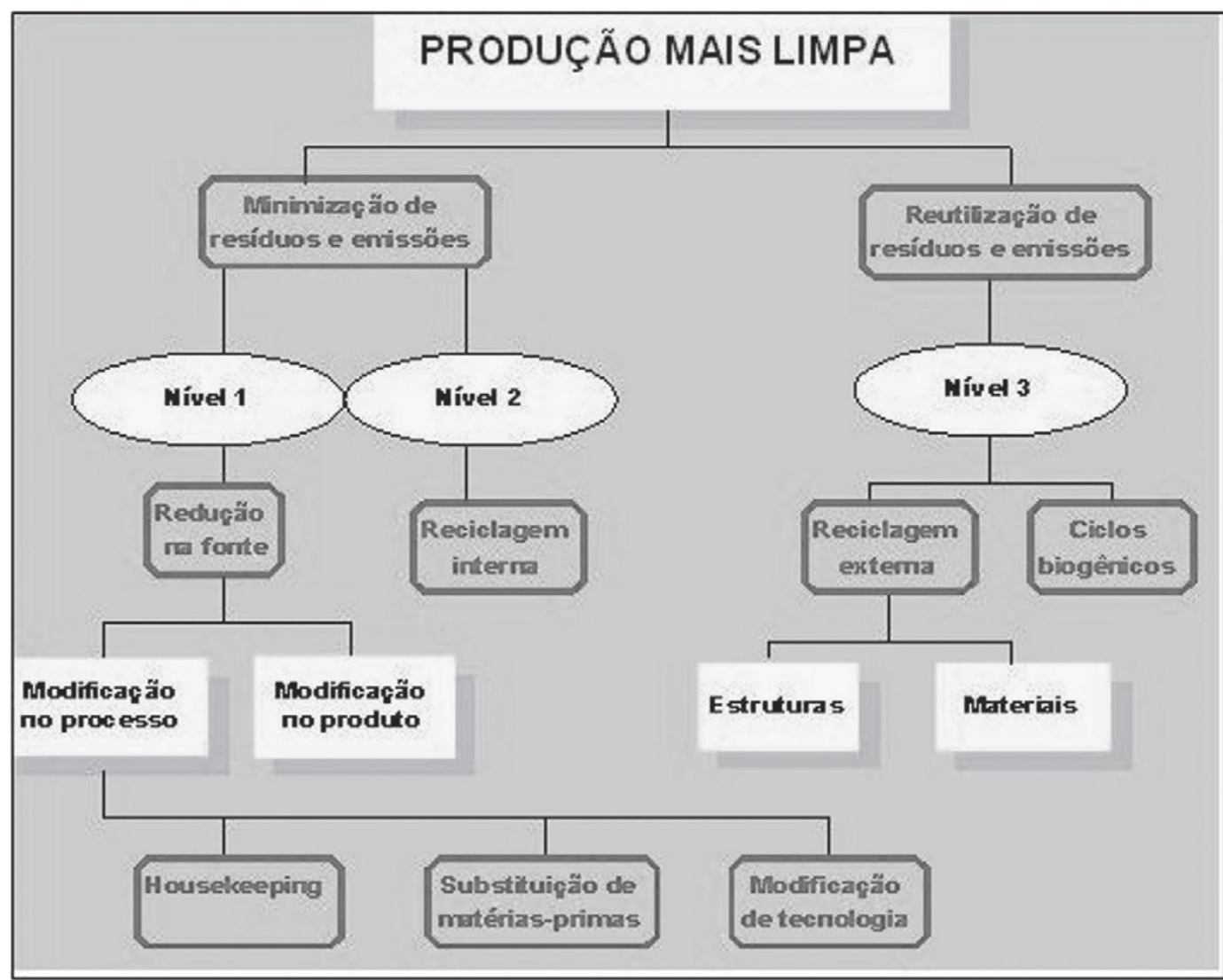

Fonte: Unido (2001, p.11) apud Nascimento (2012, p.111)

Conforme pode ser notado na figura, a prioridade da $P+L$ é o de minimizar resíduos e emissões, então no seu nível 1 seria a redução na fonte para depois ocorrer uma modificação no processo ou no produto, já no para a situação do nível 2, a empresa deverá fazer uma reciclagem interna, ou seja, o que não puder ser aproveitado deve ser reciclado de forma a incluir novamente em seus processos essa ação. Caso não seja viável nenhum dos outros níveis, a empresa deverá seguir para o nível 3 com o objetivo de reutilizar os resíduos e emissões, fazendo depois uma reciclagem externa ou ciclos biogênicos. 
Segundo (NASCIMENTO, 2012), da melhor solução para a pior solução, em ordem sequencial, temos o seguinte:

- Não geração: Essa solução, que é considerada a melhor, busca a não geração total de resíduos na produção ou durante o processo de funcionamento do serviço e/ou produto. É algo visto pelas experiências anteriores como algo impossível, uma vez que qualquer ação humana gera resíduos e poluentes, e, consequentemente, impactos ambientais.

- Minimização: Essa solução, como o próprio nome diz, busca a minimização de emissões e resíduos nos processos de produção e funcionamento do serviço e/ou produto. Tem uma busca mais acessível e palpável para a realidade atual a muitos tipos de negócios.

- Reciclagem interna: Essa solução busca o reaproveitamento de resíduos gerados nos processos de produção e funcionamento do serviço e/ou produto.

- Reciclagem externa: Essa solução tem como ação a contratação de uma empresa externa para realizar o aproveitamento dos resíduos gerados nos processos de produção e funcionamento do serviço e/ou produto, não havendo a reintegração desses resíduos na produção.

- Disposição final: Essa solução, que é considerada a pior, é o despejo desses resíduos gerados nos processos de produção e funcionamento do serviço/produto sem seu reaproveitamento.

Ainda segundo (NASCIMENTO, 2012), somente após as técnicas de prevenção serem adotadas por completo é que se deverá utilizar as opções de reciclagem, assim, somente após a reciclagem é possível considerar o tratamento. "A $\mathrm{P}+\mathrm{L}$ não significa maximizar o uso de reciclagem ou as tecnologias de controle da contaminação, conhecidas como tecnologias fim-detubo*, antes da prevenção” (NASCIMENTO, 2012, p. 112).

Nascimento (2012, p.112) defende que "a Produção Mais Limpa envolve saber aproveitar os equipamentos e as tecnologias existentes, com o objetivo de gerar o mínimo impacto possível". 
Sendo assim, com a perspectiva de garantir o desenvolvimento sustentável e enfrentar novos caminhos da competitividade industrial, a estratégia de estruturar um Sistema de Gestão Ambiental nas organizações pode ser considerada como uma fonte de oportunidades e não como um obstáculo. Dentro desta estratégia, adotar a $\mathrm{P}+\mathrm{L}$ resulta em uma alternativa viável para o sucesso dos objetivos organizacionais (NASCIMENTO, 2012, p. 113).

\title{
2.5. Economia Circular
}

"A economia circular é uma nova forma de olhar as relações entre o mercado, clientes, recursos naturais e a sociedade" (WBCSD, 2017 apud CEBDS, 2018, p.4). De acordo com a economia clássica, ou linear, toda a produção é baseada em produzir, consumir e depois eliminar, porém, essa forma não será mais sustentada, a natureza já atingiu todos os limites possíveis. Com todas as ações absurdas que o humano faz ao meio ambiente, a única alternativa é a busca por novas medidas que possam, no mínimo, minimizar tamanho impacto.

\begin{abstract}
O modelo econômico 'extrair, produzir, desperdiçar' da atualidade está atingindo seus limites físicos. A economia circular é uma alternativa atraente que busca redefinir a noção de crescimento, com foco em benefícios para toda a sociedade. Isto envolve dissociar a atividade econômica do consumo de recursos finitos, e eliminar resíduos do sistema por princípio. Apoiada por uma transição para fontes de energia renovável, o modelo circular constrói capital econômico, natural e social (ELLENMACARTHUR FOUNDATION, 2021a).
\end{abstract}

Segundo CEBDS (2018) e de acordo com Ellen MacArthur Foundation, são três os princípios básicos que são necessários para a aplicação do modelo de economia circular:

- Preservar e aumentar o capital natural. Conta como princípio básico aumentar o capital natural sem degradar o meio ambiente e compreende a utilização de recursos renováveis ou que possam apresentar melhor desempenho.

- Otimizar a produção de recursos. Vem do conceito básico de que nada se perde, tudo se transforma, logo, a produção é pensada toda para a reciclagem e reforma, dando-se nova vida àquilo que não serviria a mais ninguém. Com isso uma utilidade é dada novamente ao produto. 
- Fomentar a eficácia dos processos. Mapear, analisar e reproduzir os bons resultados que um processo pode ter, a fim de não ter grandes despesas e prejuízos ao meio ambiente, mas pensando também na lucratividade.

A implantação de uma economia circular se baseia em preservar e valorizar o capital natural e minimizar o desperdício, atuando em todos os elos da cadeia, desde a concepção, até a distribuição e reentrada no ciclo; "As palavras de ordem são PRESERVAÇÃO, VALORIZAÇÃO E MINIMIZAÇÃO" (CEBDS, 2018, p.6).

Figura 5 - Elos da Economia Circular

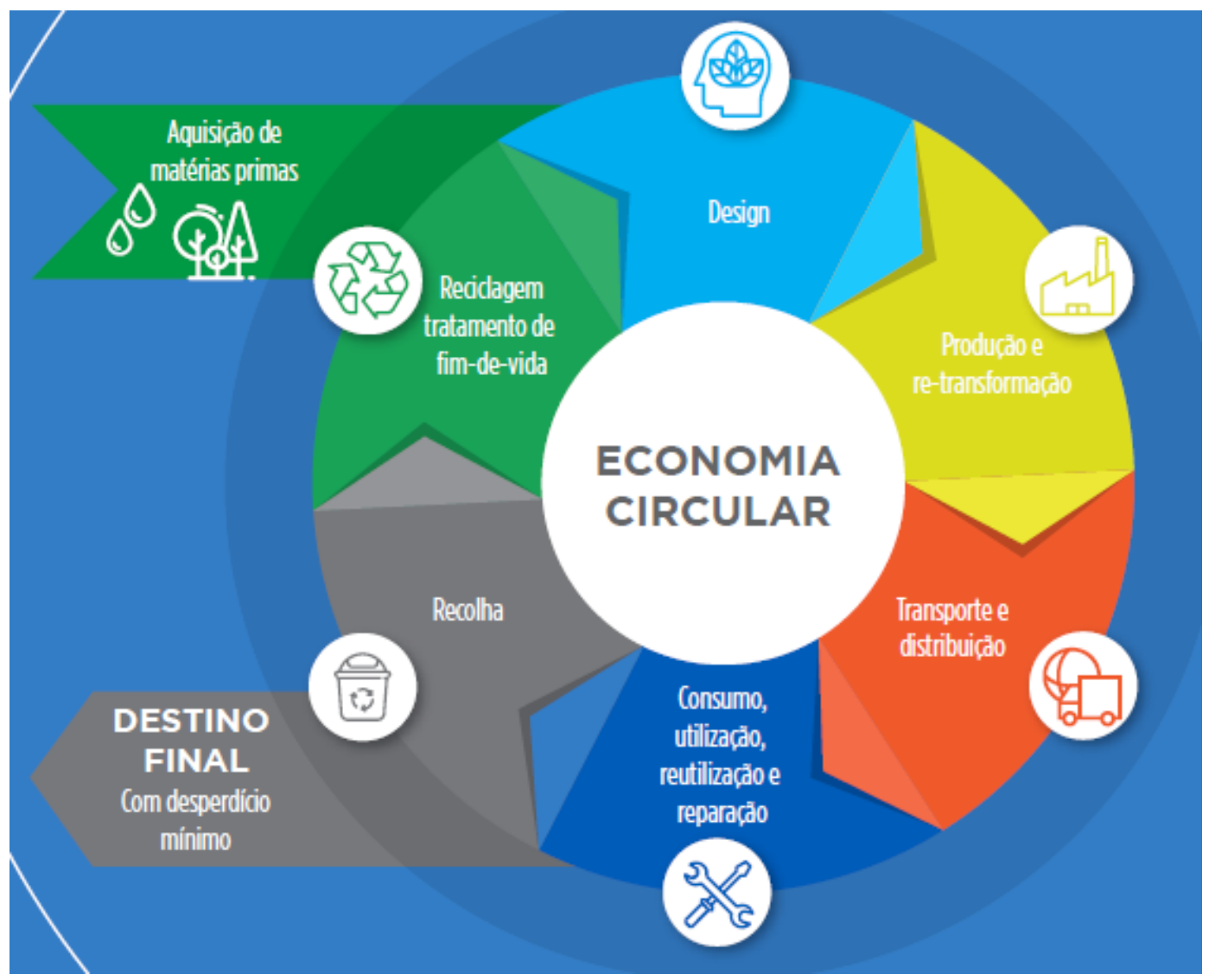

Fonte: CEBDS (2018, p.13)

No primeiro elo da cadeia (figura 5), concepção e o design, se torna importante o desenvolvimento de produtos mais duradouros e com um maior ciclo de vida. Durante a produção o foco está na concepção de processos mais limpos, para que no transporte e distribuição a alternativa seja de modos de transportes mais sustentáveis e da utilização de materiais recicláveis (CEBDS, 
2018). No consumo e utilização, o intuito é de melhoria da eficiência energética, maximização da vida útil do produto e otimização da reparação e reutilização. Por fim, o mesmo autor relata sobre a reentrada do produto no ciclo, através da dinamização de redes de retorno, reuso remanufatura e reciclagem.

De acordo com Barbieri (2007, p.164) a ISO 14040 define ciclo de vida como "estágios consecutivos e interligados de um sistema de produto, desde a aquisição da matéria-prima ou extração dos recursos naturais até a disposição final. Nascimento (2012, p. 66) apresenta 5 Rs dentro da gestão ambiental que são condizentes com a economia circular, são eles:

- Reduzir;

- Reutilizar;

- Reciclar;

- Reprojetar;

- Rejeitar.

Na prática, as atividades da economia circular são pensadas "objetivando minimizar perdas sistêmicas e processos externos negativos, além de gerar valor positivo para as empresas, principalmente para os recursos naturais" (CEBDS, 2018, p.7).

Vickers (2019) na figura 6, traz de uma maneira mais prática os 4 grandes propósitos da economia circular, que são: reduzir a pegada ambiental, utilizando produtos sustentáveis, não tóxicos, duradouros e recicláveis; gerar mais demanda, através de uma produção mais limpa com menos recursos; diminuir a dependência de recursos, melhorando a manutenção e aumentando a vida útil; e minimizar resíduos, fazendo a coleta no fim da vida útil, reciclando e buscando o reuso dos recursos. 


\section{Economia Circular}

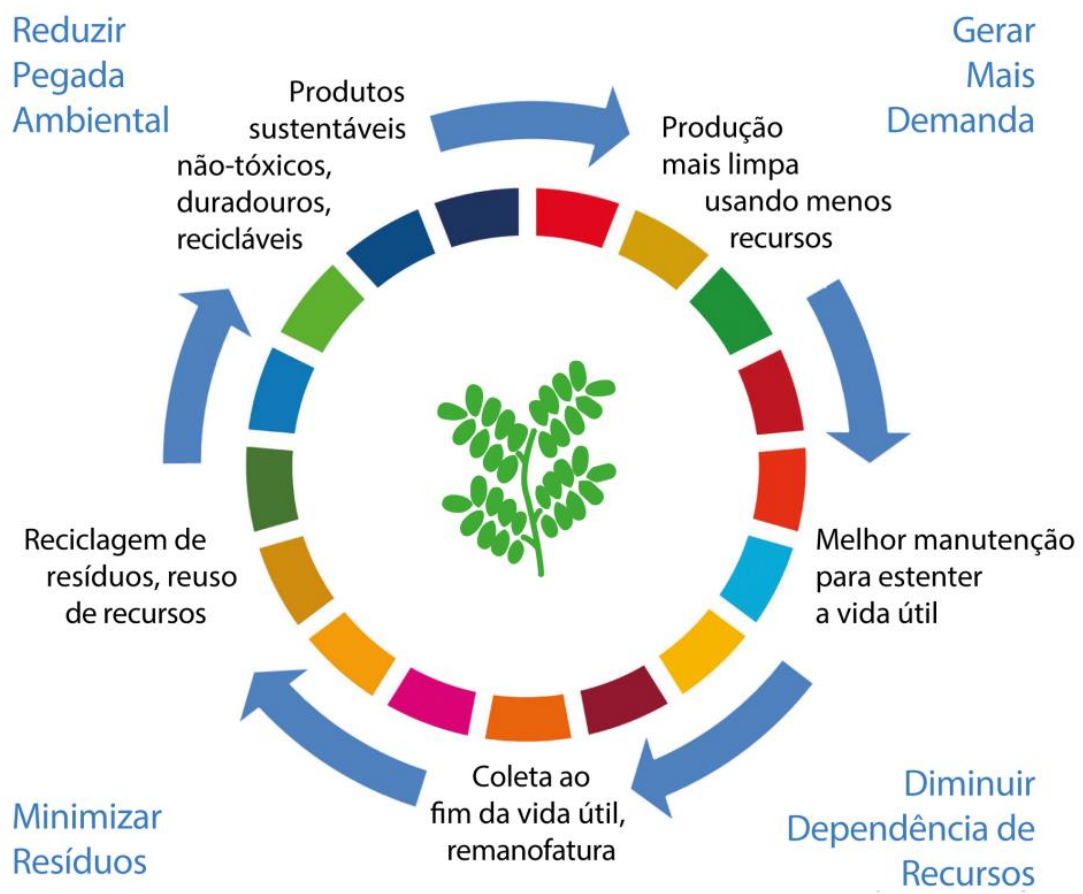

Fonte: Vickers (2019)

Este novo modelo em que a indústria busca ser regenerativa e não destrutiva, já está proporcionando oportunidades de negócios mais viáveis para enfrentar com êxito um mercado cada vez mais competitivo e com exigências ecológicas (LEITAO, 2015).

Este novo paradigma de sustentabilidade estimula novas práticas de gestão e descortina novas oportunidades adicionando valor à organização e aos clientes, em harmonia com o meio ambiente. Enquanto fonte de inovação e permitindo a redução da procura de recursos naturais com a recuperação de desperdícios e resíduos, a Economia Circular abre excelentes perspectivas a serem encaradas pelas empresas como alavanca e motivação para um crescimento com bases sólidas e com futuro, além das vantagens competitivas no contexto de um mercado global altamente dinâmico. (LEITAO, 2015, p.5) 


\subsubsection{Logística Reversa}

Os principais aspectos ambientais incorporados à gestão logística foram, inicialmente, relacionados a emissão excessiva de gases e à eficiência energética do transporte, no entanto, depois de algum tempo, outras abordagens começaram a surgir. Recentemente, começaram a ser desenvolvidas visões quanto a interação entre a logística e o meio ambiente, principalmente no que tange à gestão de resíduos sólidos (FERREIRA, 2017). A partir disso, surgiu, há alguns anos, o conceito de logística reversa, hoje já adotada em diferentes setores produtivos.

Diante do aumento da competitividade entre as empresas, da mudança dos hábitos de consumo da população e da exigência cada vez maior em se tornarem eficientemente capazes de promover atividades visando a sustentabilidade, a logística reversa começou a ganhar prioridade nos assuntos gerenciais.

O conceito de Logística Reversa é definido por Leite (2003) como a logística que planeja, opera e controla o fluxo físico e de informações, do retorno dos bens de pós-venda e de pós consumo ao ciclo de negócios ou ao ciclo produtivo. Podendo ser feito por meio de Canais de Distribuição Reversos, agregando-Ihes valor de diversas naturezas: econômico, ecológico, legal, de prestação de serviços, de imagem corporativa.

Segundo Hernandez et al. (2012, p.446), o foco da Logística Reversa é "relacionado com o retorno de bens para serem processados em reciclagem dos materiais, sendo denominados e analisados como canais de distribuição reversos".

\footnotetext{
Segundo Rogers e Tibben-Lembke (1999), a LR pode ser definida como a área da Logística Empresarial responsável pelo planejamento, operação e controle dos fluxos reversos de matérias-primas, estoques de processo, produtos acabados e as respectivas informações desde o ponto de consumo até o ponto de origem, com o propósito de recapturar valor ou adequar seu destino, podendo gerar diversos benefícios que originam ganhos de competitividade e se refletem nas esferas econômica, social e ambiental (ROGERS; TIBBEN-LEMBKE, 1999 apud HERNANDEZ et al. 2012, p.446).
} 
A logística reversa envolve o processo de planejamento, implantação e controle de todo um fluxo de uma cadeia logística, tendo que englobar o retorno desses produtos e/ou materiais para que sejam descartados ou reutilizados de forma a minimizar seu impacto ambiental. "Seu propósito é o de recuperar valor ou garantir o descarte de forma apropriada" diz Ferreira (2017, p.28).

Dessa forma, fica evidente o comprometimento que as empresas devem ter com o destino final de seus produtos, o que se relaciona diretamente com a adoção de ações de sustentabilidade e com o conceito de reciclagem. "A logística reversa surge nesse cenário motivada por exigências legais, mas também como oportunidade de negócios" (FERREIRA, 2017, p.31). 


\section{Metodologia}

De acordo com Gil (2008, p.26), "pode-se definir pesquisa como o processo formal e sistemático de desenvolvimento científico. O objetivo fundamental da pesquisa é descobrir respostas para problemas mediante 0 emprego de procedimentos científicos".

A metodologia utilizada no presente estudo foi a metodologia descritiva explicativa, tendo como base dados primários e secundários, os quais foram coletados de estudos e pesquisas em sites da internet, entrevistas não sistematizadas com integrantes da instituição, livros, artigos sobre a sustentabilidade e responsabilidade social empresarial, relatórios de sustentabilidade, materiais internos e comunicação da Stone Pagamentos S.A. Portanto, quanto aos meios, é de viés bibliográfico, documental e de campo.

Vergara (1998, p.45) expõe que a investigação descritiva é composta por características de determinada população ou de determinado fenômeno. "Pode também estabelecer correlações entre variáveis e definir sua natureza. Não tem compromisso de explicar os fenômenos que descreve, embora sirva de base para tal explicação".

Já a metodologia explicativa pode ser definida como tendo o "principal objetivo tornar algo inteligível, justificar-lhe os motivos. Visa, portanto, esclarecer quais fatores contribuem, de alguma forma; para a ocorrência de determinado fenômeno" (VERGARA, 1998, p.45).

Desse modo, é possível concluir que ambos os tipos de pesquisa estão presentes nesse estudo. A pesquisa descritiva se torna evidente principalmente no referencial teórico, o qual sustenta tópicos como a responsabilidade social empresarial, a gestão da sustentabilidade, a economia circular e a temática da operação mais limpa, como forma de contextualizar o trabalho e de salientar a existência de relações entre as variáveis. 
Como Gil (2008) destaca, as pesquisas descritivas e exploratórias constituem etapa prévia indispensável para que se possam obter explicações científicas, o que pode ser assentado nos resultados oferecidos pelos estudos explicativos. A natureza explicativa é aprofundada através do cruzamento entre os dados e informações obtidas por fontes primárias, secundárias, da coleta de dados diretamente com pessoas ligadas à instituição e através de relato de experiência, que demonstram ações de sustentabilidade, o modelo de relatório, a logística reversa e o projeto piloto de bicicletas elétricas realizado pela Stone Pagamentos S.A. com todo o estudo descritivo teórico citado anteriormente. 


\section{Histórico da Empresa}

\subsection{A Stone}

"No início dos anos 2000, o setor financeiro do país, incluindo o mercado de pagamentos, era extremamente concentrado e verticalizado, o que limitava a escolha dos clientes" (LINS; BOURROUL, 2021, p.16). De acordo com Lins e Bourroul (2021), na época, as adquirentes existentes estavam acomodadas com o seu lugar no mercado, oferecendo muitas vezes um serviço arcaico, com pouca transparência, baixa qualidade nos atendimentos aos clientes e com custos elevados.

A Stone nasceu em 22 de junho de 2012, porém, o primeiro passo foi dado anos antes, em 2004, com a fundação da Braspag, empresa criada pelo André Street e Edu Pontes, que processava os pagamentos online e que permitiu a venda pela internet. "Percebendo a qualidade dos serviços no mercado, transformar a empresa em uma adquirente era o único caminho possível para disruptar o mercado" (STONE, 2021).

Em 2009 a Braspag foi vendida e a vontade de crescer foi se intensificando, a cada dia. Em 2011 os fundadores investiram na Cappta, que basicamente faz uma conexão de um sistema de venda com uma adquirente. $\mathrm{O}$ investimento na Cappta foi muito importante para construir diversos conhecimentos e valores que a Stone possui hoje em dia, como: funcionamento das vendas no mundo físico, relacionamento sólido com o cliente, principalmente com os clientes do interior do Brasil - a Cappta tinha um foco muito grande nesses clientes -, e como se relacionar com a força de venda terceirizada.

Com a notícia, em 2012, que o Banco Central colocou fim na regra de exclusividade entre bandeiras e adquirentes, a Mundipagg foi criada, empresa de sistema de pagamentos online. Naquele mesmo ano, a Stone foi fundada, mesmo sem ter licença para operar como adquirente e com um objetivo muito claro: "ajudar os empreendedores brasileiros a vender mais, gerir melhor suas 
empresas e crescer sempre" (LINS; BOURROUL, 2021, p.18). Em seguida, em 2013, a licença para atuar como adquirente foi conquistada.

Em 2014 a primeira transação aconteceu:

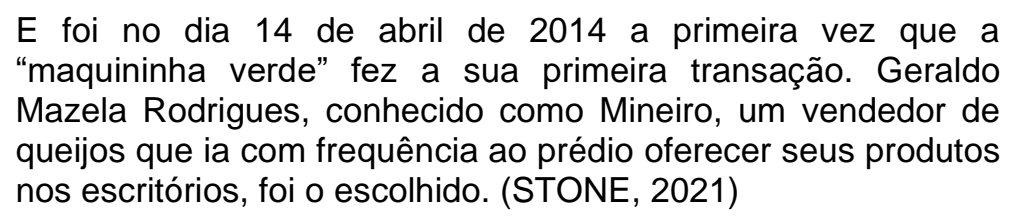

Com o crescimento da empresa e o avanço do número de clientes, 3 decisões precisaram ser tomadas para que uma transformação ocorresse. De acordo com o site da empresa Stone (2021), as decisões foram:

- Internalização do atendimento

A área de Relacionamento com o cliente foi criada, famosa $\mathrm{RC}$, a qual tinha objetivo de virar referência de atendimento no mundo, sem precisar terceirizar e com funcionários com os valores Stone para lidar com o cliente. Em 2020 , chegaram a 8.000 encantadores, com atendimento 24 horas e totalmente capazes de atender em até 5 segundos o cliente que entrava em contato para tirar dúvidas, solicitar atendimento ou mesmo, orientação.

- Criação de polos regionais

A criação dos polos surgiu, em 2015. Um dos agentes comerciais foi passar um final de semana em Cabo frio, no litoral fluminense do RJ, e não conseguiu retornar na segunda-feira por conta do trânsito na estrada. Dessa forma, depois de alinhar com o seu líder, resolveu ficar mais uns dias na cidade para verificar como seria a conversão dos lojistas da região. A meta estabelecida era de um cliente por semana, no entanto, foi surpreendido, pois, ele conseguiu três em um único dia. Logo nasceu o polo de Cabo frio para então vários outros serem criados.

- Construção da própria logística

Com a criação do primeiro polo em 2015, o time começou a ser estruturado e ganhar forma. Atualmente, em 2021, a equipe já soma mais de 500 entregadores próprios - chamados de green angels -, com um SLA (Service Level Agreement) de até 48 horas para a maquininha estar no balcão do cliente. 
O ano de 2018 foi marcado por mais uma grande conquista, a abertura de capital nos Estados Unidos, chegando à avaliação de unicórnio - startups que possuem avaliação de mercado de mais de 1 bilhão de dólares. Após quatro anos de operação, já tinham em sua base 200.000 clientes e cerca de $5 \%$ do mercado de adquirência do país (STONE, 2021).

O controle de vendas dos donos de negócio, muitas vezes, ainda acontecia por meio do espeto, que ficava ao lado das máquinas de cartão, nele que os comerciantes espetavam os comprovantes das transações e era dessa forma que realizavam o seu gerenciamento. Nesse contexto, a Stone viu a necessidade de criar um sistema de gestão automatizado para que o empreendedor consiga gerir com mais facilidade, mais transparência e principalmente, de forma mais prática o seu negócio.

"Com inovação, atendimento humano, baixo custo transacional e informações transparentes, queríamos ser os principais parceiros dos 27 milhões de empreendedores brasileiros, servindo-os de forma inédita e potencializando seu crescimento" (LINS; BOURROUL, 2021, p.20).

Com objetivo de ir além de uma máquina, a empresa começou a buscar formas de facilitar a vida do empreendedor e de unificar em um lugar tudo que o cliente necessita para que seu negócio tenha bons resultados financeiros. Afinal, os clientes necessitavam não só de uma maquininha rápida para as vendas, mas também de uma conta para receber o dinheiro, de um empréstimo para poder investir em seu próprio negócio, um sistema rápido e automático para conciliar as vendas, controle de estoque, planejar o fluxo de caixa, registrar a contabilidade, organizar a folha de pagamento, entre outros (LINS; BOURROUL, 2021).

Lins e Bourroul (2021, p.21) disseram: "Seguindo um passo de cada vez, chegamos em 2020 a um portfólio completo para os negócios brasileiros, com milhares de clientes e planos ambiciosos e construtivos pela frente." 
Figura 7 - Além da Maquininha

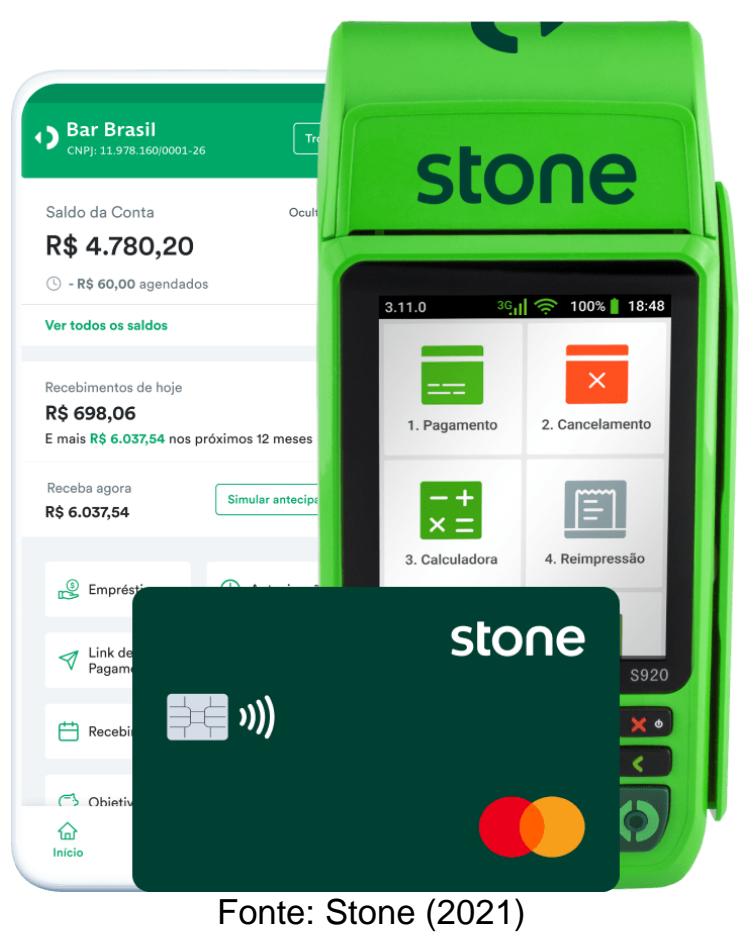

Em 2020 nasceu a Ton, uma empresa criada pela Stone, "com foco nos autônomos e microempreendedores. A nova marca nasceu para ajudar esse empreendedor em seus desafios de crescimento a partir de uma parceria com o Grupo Globo." (STONE, 2021). Assim, a empresa já contava com mais de 6 mil pessoas na equipe, mais de 600 mil clientes em todas as regiões do Brasil e 16 bilhões de dólares de valor de mercado.

Com o tempo, compreendendo o que os clientes precisavam e sempre respeitando a essência da companhia, definimos três diferenciais competitivos: o relacionamento de qualidade com o cliente, a força comercial com um modelo de distribuição inovador e a tecnologia proprietária. Se o quê era menos importante do que o como, estabelecer um jeito Stone de fazer, genuíno e particular foi o caminho para ganhar identidade e potência e, consequentemente, relevância em um mercado dominado por gigantes (LINS; BOURROUL, 2021, p.19).

O crescimento da Stone se caracteriza pela capacidade de fomentar uma cultura forte, para que pessoas saibam para onde vamos, o que estão fazendo ali, como devem se 
comportar e o que podem esperar como reconhecimento. Formar um time de excelência é inegociável desde o dia um, e ter valores claros é fundamental para que todos remem na mesma direção (LINS; BOURROUL, 2021, p.22).

\title{
4.2. A logística Stone
}

A logística da Stone é dividida em algumas áreas, no coração da operação logística estão a liga, o time de suply e o last Mile Próprio. Nesse trabalho, o foco será apenas no last Mile Próprio, nessa área estão os Green Angels e outras funções da operação. A missão dessa área é a de garantir que a última milha (tradução de last mile) seja atendida da melhor maneira possível e com eficiência, eles são a ligação entre os polos da empresa e os clientes.

\begin{abstract}
A logística é a área responsável por toda a cadeia da famosa "maquininha" de cartão. É o nosso time de logística que garante a entrega de ativos para os clientes, além de fazer 0 planejamento e controle dos estoques. No entanto, quando falamos de "entrega", estamos nos referindo a estar frente a frente com o cliente, fazendo um atendimento de excelência e surpreendendo nos quesitos eficiência e qualidade. $O$ time cuida de toda a cadeia do processo: desde a compra da máquina, até garantir a entrega na mão do cliente e trazer uma solução eficaz e rápida para qualquer contratempo que possa vir a existir (TIME STONE, 2017).
\end{abstract}

"O nome "Anjos Verdes" é um reflexo da importância dessa operação: pintar o Brasil de verde através da expansão da Stone pelo Brasil e ser o anjo do atendimento extraordinário" (TIME STONE, 2018a). Eles são os funcionários Stone que estão na ponta do processo e seu papel é o de atender o cliente da melhor maneira possível. Suas atribuições podem englobar a instalação de point of sales (as famosas maquininhas), instalação de softwares gerenciais, visitas de manutenção, troca de máquinas e desinstalação/devolução de máquinas.

Neste último ponto, esse processo de recuperação de máquinas possui um time focado, afinal existem muitos clientes que estão inativos no mercado e que já não usam a máquina, seja por razões referentes às taxas, ao aluguel ou simplesmente por terem recebido proposta de outra adquirente. Nesse momento, é importante que as máquinas sejam recolhidas não só por ser um ativo da empresa, como também por ser uma enorme oportunidade de gerar soluções mais sustentáveis e de gerir de uma forma mais qualitativa a sua gestão ambiental. 
Com a máquina tendo a possibilidade de voltar ao seu ciclo produtivo, será benéfico para a empresa pois terá redução de custos e também seguirá com uma pegada ambiental que converge com o conceito de economia circular e logística reversa.

Com o sucesso do agente comercial na cidade praiana da região dos lagos no Rio de Janeiro, a expansão da empresa e consequentemente de sua logística precisava ser pauta nas discussões dos próximos passos que a empresa daria. Com esse objetivo definido, a empresa precisou contratar mais pessoas rapidamente e os pré-requisitos iniciais eram apenas que os agentes tivessem habilitação, moto própria e disposição.

A logística Stone tem como foco a eficiência da cadeia, para atingi-la, a estratégia de distribuição precisa ser feita com muita sinergia e colaboração de vários times. O importante é sempre atender bem ao cliente, dentro do prazo e garantindo a segurança de seus funcionários.

A operação é dividida em 6 regiões do Brasil, de forma estratégica para conseguir atender todos os pontos. Além das regionais, existem os Distritos e menores unidades chamadas de polos e bunkers. Os polos são em sua maioria unidades compostas por Agentes e Green Angels e os bunkers são compostos somente por Green Angels.

Atualmente são mais de 400 polos e bases que saem os mais de 500 green angels, através de um sistema interno eles conseguem acessar todos os serviços que devem realizar no dia e os locais onde deverão prestar atendimento, sendo o primeiro passo para o planejamento da operação. Além disso, no polo, também se integram as demais atividades realizadas pelo time de backoffice (TIME STONE, 2018b).

Depois dos planos de ação para o dia e as rotas traçadas, os angels vão para as ruas já tendo o conhecimento do melhor percurso e caminho para seguir, garantindo eficiência na rota. Quanto a frota, a Stone possui uma frota de em média 400 carros e 300 motos. 
proteção, atuando de maneira rigorosa nas regras de
segurança e fomentando uma mentalidade de direção
preventiva, com discussões e um treinamento prático assim
que os Green Angels são contratados. Para Marina Rosa,
analista de segurança do time, é fundamental todos fazerem a
sua parte quando o assunto é segurança. (TIME STONE,
2018a).

A cadeia logística é o aspecto base de qualquer operação, de qualquer empresa, e partindo desse ponto, a funcionalidade dela pode significar um grande sucesso para a organização, como também um fracasso. Agilidade, qualidade no atendimento e custo para o consumidor são os principais valores relacionados à Eficiência Logística.

A logística faz parte do processo de gestão de uma cadeia de suprimentos e para que ela seja eficaz, ela precisa tomar as melhores decisões para o processo logístico, enquanto uma cadeia eficiente é aquela que realiza os processos da melhor maneira possível. Dito isso, o essencial para qualquer empresa é uma cadeia que englobe os dois conceitos. 


\section{Apresentação e análise}

Nesta seção serão analisadas as principais iniciativas da Stone e seu posicionamento em relação a Responsabilidade Socioambiental, a importância de uma operação mais limpa e uma logística reversa eficiente. Será dado um foco especial na recuperação de máquinas por parte da empresa e na relação de algumas operações da logística com o uso de bicicletas elétricas.

Os dados foram coletados a partir de uma experiência própria de atuação na área de recuperação de terminais como analista, a partir de uma entrevista informal não sistematizada com uma colaboradora, responsável pela área de desenvolvimento, e com o Francisco Laudo de Camargo, responsável pelo projeto piloto de bicicletas elétricas.

\subsection{Recuperação de Terminais}

Toda a logística voltada para a recuperação de terminais, foi desenvolvida por um time de pessoas muito determinadas, cheias de energia, proativas e com muita vontade de fazer a diferença. O time começou bem enxuto, na verdade, com apenas 2 pessoas de uma empresa terceira que passavam o dia ligando para clientes que possuíam algum tempo sem utilizar às máquinas Stone.

O objetivo começou humilde e de certa forma bem diretivo para que recuperassem um ativo da empresa, afinal as máquinas são compradas de uma empresa terceira. $O$ time de compras solicita o pedido das maquininhas avaliando o estoque existente e de acordo com a demanda.

Após a compra, elas são encaminhadas para os centros de distribuição e no CD avaliam as regiões que precisam receber as máquinas, para então, serem levadas para os bunkers e polos de todo Brasil. No próximo passo do processo as máquinas são direcionadas aos clientes, através dos angels, que fazem tanto o processo de instalação, como também de orientação para que os lojistas possam manusear a máquina da maneira correta. Essa parte do processo é 
essencial para que os angels conquistem ainda mais o cliente e o fidelizem, oferecendo um atendimento de excelência e eficiência.

A regra para os clientes inativos envolve aqueles que estão entre 60 e 90 dias sem utilizar, como também os com mais de 90 a 180 dias. Se o cliente entrar nessa régua ele já será propício a receber algum contato de um integrante do time de recuperação de terminais a fim de entender a razão da inativação e se o cliente tem a vontade de devolver, caso positivo, uma visita de desinstalação será agendada.

No momento que o angel vai até o cliente para cumprir a ordem de serviço de desinstalação, ele busca a máquina para levar ao polo ou bunker de sua região. Depois que as máquinas chegam aos bunkers, são encaminhadas aos centros de distribuição para uma revitalização e manutenção. Após isso, as que estão em pleno funcionamento são direcionadas de volta para a cadeia, sendo integrada no estoque disponível de máquinas e indo para outro cliente. Caso a máquina apresente defeito e não tenha sido possível a reparação, ela será encaminhada para uma empresa terceira, regulada pela ISO 14000, a qual irá fazer o descarte e/ou reciclagem adequada para a máquina e seus componentes.

Os processos recém descritos, englobam etapas essenciais da economia circular, com o encaminhamento das máquinas que não puderam ser reparadas a uma empresa terceira para que faça a reciclagem/descarte corretamente, a renovação/remanufatura, fazendo o conserto das máquinas com defeito e a reutilização, para que possam voltar ao ciclo da logística e prolongar o seu ciclo de vida.

Dito isso e tendo com base o estudo da Ellen Macarthur Foundation (2021b), a empresa desenvolveu formas de facilitar o reuso, a reciclagem e o aproveitamento dos produtos em seu ciclo. A mesma autora ressalta: "O design de produtos e processos, requer habilidades, conjuntos de informação e métodos de trabalho avançados". Logo, todo o processo de recuperação das maquininhas é puramente um exemplo de economia circular e logística reversa.

Algumas são as práticas que podem ser apresentadas como vantagens para a empresa de ser sustentável, como: economia de custos, economias 
ligadas à reciclagem, melhoria na imagem institucional e na entrega de valor dos produtos e serviços oferecidos, maior identificação dos funcionários com a empresa, melhor adequação aos padrões de sustentabilidade corporativa, entre outros.

Logo, a Stone parece ambiciosa em relação a atingir um desenvolvimento sustentável com a gestão cada vez mais eficiente de seus processos e continuamente engajados com a responsabilidade social empresarial. Caminha, também, dentro dos conceitos ligados à operação mais limpa com os ajustes no processo produtivo a fim de reduzir a geração de diversos resíduos ligados às maquininhas e à toda cadeia logística de distribuição.

Como revelado durante a pesquisa, existem algumas exigências para que uma empresa obtenha o certificado ISO 14000, e a Stone ainda não as possui. Com a certificação seria possível fazer um acompanhamento mais claro de suas ações com o objetivo de gerar impactos positivos no meio ambiente. Apesar das práticas já realizadas atualmente, a empresa ainda precisa caminhar um bom percurso para que consiga alcançar alguns padrões ambientais, pois, atualmente, essas práticas são diretivas a determinados processos e será necessária ainda uma transformação do sistema como um todo.

A partir da análise de resultados, fica evidente o quanto a empresa está comprometida em ser mais responsável ambientalmente, economicamente e socialmente, e de apresentar as suas práticas para que seja de ciência nacional, mostrando a sua ambição para alcançar um desenvolvimento mais sustentável.

\subsection{Outros Projetos Iniciais}

Existem outras iniciativas da empresa que serão destacados nos próximos tópicos desse estudo a fim de contextualizar as práticas adotadas e enriquecer as informações sobre sua gestão da sustentabilidade de forma evidenciar os caminhos que estão sendo percorridos.

\subsubsection{Relatório de Sustentabilidade}

Mediante definição do tema do trabalho, foi possível buscar internamente na empresa Stone Pagamentos S.A. funcionários que pudessem informar sobre 
as ações ambientais existentes, como também as futuras. Através de uma conversa informal com uma colaboradora da área de desenvolvimento, foi possível obter a informação de que a empresa está em processo de elaboração do seu primeiro relatório de sustentabilidade.

No mês de maio de 2021, através de uma entrevista informal não sistematizada, foi exposto que a estimativa é que o primeiro relatório da empresa seja publicado em breve, com informações pertinentes, extremamente esclarecedoras, condizentes com a cultura da empresa e seguindo o padrão GRI no que tange ao âmbito do meio ambiente.

Seguindo o padrão GRI a Stone mostra o interesse em medir o seu desempenho, os seus impactos econômicos, ambientais e sociais de forma mais diretiva, responsável e transparente. A empresa possui essa deficiência na exposição dos indicadores de sustentabilidade, no entanto, demonstra clara expectativa em conseguir adotar o relatório de forma que se torne recorrente a divulgação nos próximos anos.

\subsubsection{Uso de Bicicletas elétricas}

Existe um movimento muito forte no mundo em torno da mobilidade urbana, sendo necessário buscar meios mais limpos de se locomover e de promover um menor impacto ambiental.

Foi em 2019 que a bicicleta elétrica ganhou um código exclusivo, 3091.2005. Antes disso e pelo menos durante alguns anos ela foi atrelada às informações sobre motocicletas e outros ciclomotores, ou seja, os seus dados de produção e vendas eram armazenados e disponibilizados como se fossem provenientes desses tipos de transportes (REVISTA BICICLETAS ELÉTRICAS, 2020).

Segundo a Revista Bicicletas Elétricas (2020, p.21):

Em média cerca de 4 milhões de unidades são vendidas por ano. Ainda segundo os mesmos dados, em 2018, foram comercializadas cerca de 4,06 milhões de unidades, um aumento de $7 \%$ em relação a 2017 , ano em que foram vendidas 3,79 milhões de unidades e uma diminuição de $6 \%$ do número de unidades vendidas se comparado com as 4,29 
milhões de unidades em 2016. Apesar da estabilidade do mercado, observa-se um aumento expressivo no faturamento do setor. A indústria da bicicleta no Brasil gerou, em 2018, um faturamento de 1,08 bilhão de reais, representando um aumento de $20 \%$ em relação a 2017 e $25 \%$ se comparado ao ano de 2016.

\subsubsection{Projeto Piloto na Stone}

Com o intuito de trazer cada vez mais qualidade, segurança e agilidade no atendimento ao cliente, a ideia de utilizar bicicletas elétricas surgiu. Em uma entrevista informal não sistematizada com Francisco Laudo de Camargo, analista de novos negócios da área de logística da Stone, foi possível entender melhor sobre esse projeto piloto.

Inicialmente, a ideia é que as bicicletas sejam utilizadas em locais de maiores densidades populacionais das cidades de São Paulo e Rio de Janeiro. As bicicletas elétricas possuem um motor elétrico auxiliar, com potência nominal de 350 Watts, velocidade máxima de $25 \mathrm{~km} / \mathrm{h}$, uma média de autonomia de $25 \mathrm{a}$ 30 quilômetros e 4 horas de duração de bateria. Conforme relatado no estudo que a empresa possui frota própria, para o caso das bicicletas, em um primeiro momento, elas seriam alugadas através de parcerias com empresas de aluguel de bicicletas.

O maior objetivo do projeto é o de reduzir custos de operação e de manutenção, afinal, atualmente, a frota é em sua totalidade composta somente por carros e motos movidos à combustão. Portanto, com a implementação das bicicletas elétricas em parte da operação, uma redução significativa já seria alcançada.

Atrelado a esse objetivo, a diminuição do impacto ambiental se torna evidente, afinal, com a redução da frota de motores movidos à combustão, a emissão de CO2 será reduzida. A estimativa é que com essa ação a empresa possa diminuir as suas emissões de gás carbônico em uma média de pelo menos $14.3 \mathrm{~kg} \mathrm{CO} 2$ anual, pensando na substituição desses veículos pelas bicicletas em distâncias curtas de no máximo 30 quilómetros.

Como benefício para a operação foi citado uma maior produtividade, maior facilidade de locomoção, afinal os agentes poderão fazer diversas viagens a 
curta distância e em tempos curtos, por não pegarem trânsito. Outro ponto importante se trata da segurança dos angels, questão que é tratada pela empresa com bastante seriedade e compromisso.

Algumas das dificuldades relatadas nesse projeto piloto foi a de encontrar um local para o carregamento das baterias das bicicletas, pois no Rio de Janeiro, por exemplo, o bunker mais próximo da zona sul - onde seria o local escolhido para os atendimentos - fica no shopping Downtown, cerca de 19 quilômetros do bairro de Copacabana. Considerando isso, para o angel sair do shopping Downtown e fazer um atendimento no bairro de Copacabana, ele teria que carregar a bateria de sua bicicleta pelo menos 1 vez ao longo do dia, pois com a autonomia da bicicleta ele não consegue ir e voltar percorrendo $19 \mathrm{~km}$ em cada trajeto sem carregá-la.

Outro ponto de dificuldade seria a de encontrar locais para armazenagem durante a noite, pois caso o angel precisasse fazer algum atendimento em uma distância mais longa, poderia correr o risco de não conseguir voltar para o bunker de armazenagem.

Um outro desafio a ser superado é o fato de que as motos e os carros possuem um espaço para armazenamento de equipamentos suficientemente adequados para as operações de rotina, no entanto, com as bicicletas, esse espaço é reduzido. Um baú de moto possui uma capacidade média de 90 litros, já na bicicleta, ele seria de 20 litros.

Alternativas que podem ser apresentadas como medida resolutivas das dificuldades apontadas são:

- Encontrar polos comerciais estratégicos para o carregamento durante o dia e armazenamento das bicicletas durante a noite, por meio de parcerias.

- Alforjes ou mochilas de lona para os angels utilizarem nas bicicletas. Um alforje é uma bolsa com diversos compartimentos que possui dois lados para ter um equilíbrio de pesos, ele pode aumentar a capacidade da bicicleta elétrica em até 60 litros. As 
mochilas de lona são bem resistentes e podem ter capacidade entre 40 e 60 litros.

Portanto, nesse momento, a empresa precisa continuar buscando medidas de contorno para as dificuldades encontradas, apontar os gargalos que a operação já possui e mapear todas os planos de ação. Dessa forma, seguirão eficientes em busca de construir a sua responsabilidade social empresarial e a gestão de suas ações sustentáveis.

\subsubsection{Referências no Mercado}

Devido ao aumento dos números de casos de covid no país e das novas medidas de restrição adotadas por diversas cidades, a demanda de pedidos, compras e serviços em casa se intensificou muito. Com isso, a preocupação com a emissão de gases poluentes também cresce.

De olho nos novos hábitos e preocupados com o impacto no meio ambiente, a empresa Ifood lançou um programa voltado para a sustentabilidade, chamado Ifood Regenera (GIMENES, 2021). Gimenes (2021) relata que o plano do Ifood é de "contar com 10 mil motos elétricas em até 12 meses, e de realizar $50 \%$ das entregas em modais não poluentes até 2025."

A proposta da empresa é a de estimular esse meio de transporte oferecendo linha de crédito especial para os seus entregadores, no entanto o desafio é a escala, pois produção, demanda e crédito existem (GIMENES, 2021). Barateando custos e tornando as bicicletas economicamente viáveis para uma pessoa comprar, o que fica faltando é a divulgação do projeto para que cada vez mais entregadores participem (GIMENES, 2021).

Outra empresa que vem inovando e utilizando veículos elétricos em suas operações é a B2W, empresa dona da Americanas.com, Submarino e Shoptime. Ela está "acrescentando mais uma roda à estratégia de limpar sua pegada de carbono na "última milha" do e-commerce" (SETTI, 2021). Segundo Setti (2021), O projeto começará inicialmente a entregar pacotes em áreas de alta densidade populacional de São Paulo e do Rio de Janeiro através de 90 tuk-tuks elétricos, podendo comportar até 600 quilos. 
"A expectativa da B2W é que os tuk-tuks evitem a emissão de 3 toneladas de CO2 por mês, segundo Welington Souza, diretor da LET'S, plataforma de gestão de logística e distribuição da Americanas e da B2W." (SETTI, 2021)

Figura 8 - Tuk-Tuks elétricos

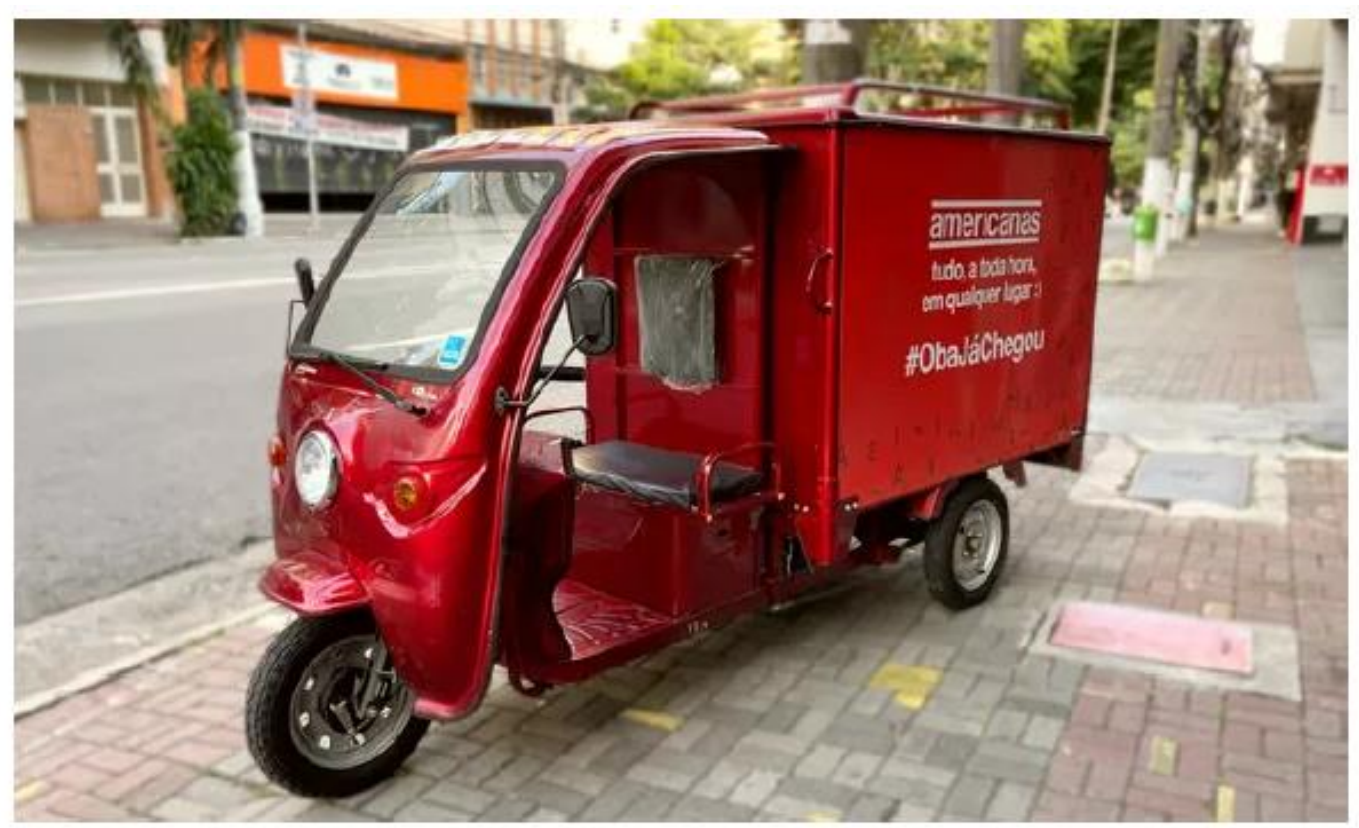

Fonte: SETTI (2021) 


\section{Conclusões e Sugestões}

Ao longo do presente estudo foram levantadas algumas mudanças que 0 mundo vem sofrendo devido às atividades humanas e que desencadeiam inúmeros prejuízos ao meio ambiente. Entre eles estão o crescimento populacional desmedido, consumo exacerbado de matéria-prima, crescente aumento de resíduo e contínua delapidação de recursos. Com isso, a questão da sustentabilidade e da responsabilidade socioambiental está ganhando cada vez mais força e a sua discussão se torna de extrema importância, tanto por parte da população, como também das empresas.

Neste sentido, as empresas precisam encarar esses novos desafios impostos pelo desenvolvimento sustentável e recriar os seus processos, aplicar novas formas de produzir e sustentar novas atitudes, necessitando de ações mais responsáveis. Dito isso, foram analisados diferentes aspectos sobre a empresa Stone Pagamentos S.A. e as suas ações como forma de minimizar os impactos gerados.

Como uma empresa que vêm crescendo muito nos últimos anos e conhecida por ter um ambiente de pessoas mais jovens, cheias de energia e com muita vontade de fazer a diferença, esse tipo de atitude é mais do que esperada por seus stakeholders. Afinal, é totalmente possível uma organização atingir o crescimento econômico sendo responsável com o meio ambiente.

De acordo com o fundamento apresentado sobre empresas sustentáveis, a Stone precisa desenvolver estratégias socioambientais no seu processo de negócio, de forma a atender as necessidades atuais fazendo o uso de recursos de forma sustentável e buscar manter o equilíbrio em relação à reciclagem, reuso. Com base na não evidência de seus processos adotados, na falta de divulgação, bem como nos seus projetos ainda em fase de testes e elaborações, fica claro que a empresa tem muito a avançar nessa perspectiva. 
Com a futura publicação de seu relatório de sustentabilidade, que na parte ambiental seguirá o modelo GRI, ficará mais evidente as suas contribuições em direção ao desenvolvimento sustentável e as definições de suas diretrizes. Neste sentido, apesar de terem o intuito de tornar o processo de produção mais eficiente, seguro e limpo, a empresa ainda não possui certificado da ISO 14000 e, com ele, seus produtos e serviços poderiam ser reconhecidos internacionalmente e se distinguiria daquelas organizações que somente atendem às legislações ambientais.

Podemos inferir que existem muitos mecanismos que auxiliam as empresas no alcance do desenvolvimento sustentável, no entanto, fica a critério delas decidirem adotá-los e se comprometerem com a sua implementação, assumindo o papel que o momento atual exige. Pela relevância do assunto, organizações de pequeno a grande porte devem se preocupar em gerir o negócio de maneira ecologicamente correta. Dito isso, a implementação da ISO 14000 se torna imprescindível para os que desejam crescer e expandir de forma sustentável.

Outro ponto, dentro do tema de sustentabilidade corporativa e do tripé da sustentabilidade, as ações ligadas ao viés econômico e ao viés ambiental estão sendo elaboradas, no entanto, as ações voltadas para o âmbito social são objeto de dúvida, mostrando que ainda é preciso assumir de forma efetiva a responsabilidade social e fazer um esforço para que seja desenvolvido todo o tripé como um fundamento integrado.

Em relação às emissões de $\mathrm{CO} 2$, o que a empresa mais gera de impacto é na sua cadeia logística, com a utilização de carros e motos movidos à combustão, entretanto não foi possível quantificar o real impacto dessas emissões em toneladas para que seja feita a conversão para créditos de carbono. Exatamente por estar preocupada com essas emissões, o projeto piloto das bicicletas elétricas surgiu e já está em produção, mas o mesmo ainda se mostra com algumas dificuldades a serem superadas e com a clara necessidade de ter objetivos mais precisos para que alcancem o resultado esperado. Com isso, este estudo poderá desencadear uma iniciativa para que a empresa reflita e se preocupe em olhar ainda mais para esse aspecto, a fim de estudar uma possível frota, no futuro, de carros elétricos. 
Seguindo o conceito da operação mais limpa, a Stone está desenvolvendo seu sistema de gerenciamento ambiental (SGA) em um caminho muito firme, tornando suas operações diárias mais sustentáveis para a redução dos resíduos e adotando uma abordagem mais preventiva em relação aos seus processos produtivos, principalmente na parte da recuperação de terminais. Dessa forma, a empresa se adequa visando a minimização de seus resíduos nos processos de produção, a reciclagem interna fazendo o reaproveitamento desses resíduos principalmente com a logística reversa - e a reciclagem externa com a contratação de uma empresa terceira para realizar o aproveitamento, descarte e/ou reciclagem.

Com esse novo paradigma em que as empresas estão buscando ser mais regenerativas e não destrutivas em seus processos, surge uma oportunidade interessante para a Stone evidenciar o quanto está engajada na economia circular e na logística reversa, para que desse modo, cada vez mais otimize a produção de recursos, fomente a eficácia dos processos e minimize o desperdício. A divulgação do relatório de sustentabilidade se mostra essencial para esse ponto.

À luz do exposto, pode-se concluir que, com base na avaliação dos processos adotados, a empresa poderia se tornar pioneira no ramo de adquirência como uma fintech que não só almeja desenvolvimentos econômicos, como também desenvolvimentos sociais e ambientais. Mostrando a sua consistência, confiança e dando exemplo para com os milhares de clientes por todo o Brasil, os influenciando positivamente no caminho para uma economia mais sustentável e limpa.

Este trabalho, assim como as análises expostas, poderá ter uma futura contribuição no âmbito acadêmico e empresarial, pelo fato de inspirar novas alternativas de minimização dos impactos gerados e ressaltar que as empresas precisam encarar os novos desafios estabelecidos para se obter um desenvolvimento sustentável.

Em relação à estudos futuros, o trabalho mostra potencial para ser explorado em uma pós-graduação, contando com uma abordagem sobre o relatório de sustentabilidade que será divulgado, prosseguir com a discussão sobre responsabilidade socioambiental e economia circular. 


\section{Referências Bibliográficas}

BARBIERI, J. C. Gestão Ambiental Empresarial: Conceitos, Modelos e Instrumentos. São Paulo: Editora Saraiva, 2007.

BASSETTO, L. I. A incorporação da responsabilidade social e sustentabilidade: um estudo baseado no relatório de gestão 2005 da companhia paranaense de energia - COPEL, Gest. Prod., v. 17, n.3, p.639-651, 2010.

BLOG JORNADA STONE. Green Angels: Nossos guerreiros das soluções das ruas. Rio de Janeiro, 2018. Disponível em: <https://jornadablog.stone.com.br/green-angels-guerreiros-das-ruas/>. Acesso em: 26 de abril. 2021.

CEBDS - Conselho Empresarial Brasileiro Para o Desenvolvimento Sustentável. 5 perguntas para você entender a Economia Circular. 2018. Disponível em: < https://cebds.org/publicacoes/5-perguntas-pra-voce-entender-economiacircular/\#.YKrgw6hKjIW>. Acesso em: 23 de maio. 2021

Coletânea Mercado de Bicicletas no Brasil. Revista Bicicletas Elétricas, São Paulo: Aliança Bike; LABMOB, no 1, p.47, 03 set. 2020.

CORAL, E. Modelo de Planejamento Estratégico para a Sustentabilidade Empresarial. Florianópolis, 2002. 270 p. Tese de Doutorado (Programa de PósGraduação em Engenharia de Produção) - Departamento de Engenharia de Produção: Universidade Federal de Santa Catarina.

ELLEN MACARTHUR FOUNDATION (org.). Economia Circular. Disponível em: https://www.ellenmacarthurfoundation.org/pt/economia-circular/conceito. Acesso em: 29 mai. 2021a. 
ELLEN MACARTHUR FOUNDATION (org.). Economia Circular. Disponível em: $<$ https://www.ellenmacarthurfoundation.org/pt/economia-circular/elementosbasicos>. Acesso em: 29 mai. 2021b.

ESTADÃO CONTEÚDO. Mercado de crédito de carbono entra na mira de empresas. Disponível em: <https://www.em.com.br/app/noticia/economia/2020/08/31/internas_economia,11 80918/mercado-de-credito-de-carbono-entra-na-mira-de-empresas.shtml>. Acesso em: 10 de maio. 2021.

FERREIRA, L. P. R. Logística Reversa: Uma proposta de destinação sustentável de equipamentos de segurança, tecnológicos e mobiliário de instituições bancárias. Brasília, 2017. 53 p. Trabalho de Conclusão de Curso (pós-graduação em Gestão Aplicada à Logística) - Centro Universitário de Brasília (UniCEUB/ICPD).

GIL, A. C. Métodos e Técnicas de Pesquisa Social. 6. ed. São Paulo: Atlas S.A., 2008.

GIMENES, D. iFood quer frota com 10 mil motos elétricas nos próximos 12 meses. Veja, 29 mar. 2021. Disponível em: < https://veja.abril.com.br/economia/ifood-quer-frota-com-10-mil-motos-eletricasnos-proximos-12-meses/>. Acesso em: 05 de abril de 2021.

HART, S. L; MILSTEIN, M. B. Criando Valor Sustentável. RAE Executivo, v. 3, n.2, p.65-79, maio-julho de 2004.

HERNANDEZ, C. T; MARINS, F. A. S.; CASTRO, R. C. Modelo de Gerenciamento da Logística Reversa. São Carlos, v.19, n.3, p.445-456, 2012.

JACOBI, P. Educação Ambiental, Cidadania e Sustentabilidade. Cadernos de Pesquisa, n.118, p.189-205, 2003.

LEITAO, A. Economia circular: uma nova filosofia de gestão para o séc. XXI. Portuguese Journal of Finance, Management and Accouting (PJFMA), v. 1, n.2, 2015. 
LEITE, Paulo Roberto. Logística reversa: meio ambiente e competitividade. São Paulo: Pearson Prentice Hall, 2003.

LINS, A.; BOURROUL, M. 5 segundos: 0 jeito Stone de servir o cliente. São Paulo: Porfolio-Penguin, 2021.

MACHADO FILHO, C. P. Responsabilidade Social e Governança: o debate e as implicações. São Paulo: Pioneira Thomson Learning, 2006.

NASCIMENTO, L. F. Gestão Ambiental e Sustentabilidade. Florianópolis: Universidade Federal de Santa Catarina - UFSC, 2012.

NOSSO FUTURO COMUM (Relatório Brundtland). Comissão Mundial sobre o Meio Ambiente e Desenvolvimento. Rio de Janeiro: Editora da Fundação Getulio Vargas, 1991.

PAZ, F. J.; KIPPER, L. M. Sustentabilidade nas organizações: vantagens e desafios. GEPROS. Gestão da Produção, Operações e Sistemas, Bauru, Ano 11, no 2, p. 85-102, abril-junho de 2016.

REDE BRASIL DO PACTO GLOBAL, 2019. Cartilha Pacto Global. Disponível em: < https://www.pactoglobal.org.br/assets/docs/cartilha_pacto_global.pdf>. Acesso em: 23 de maio. 2021.

SABBAGH, R. B. Gestão Ambiental. São Paulo: Secretaria do Meio Ambiente, 2011.

SETTI, R. B2W, dona dos sites Americanas e Submarino, coloca tuk-tuks elétricos para fazer entregas. O Globo, 28 mar. 2021. Disponível em: < https://blogs.oglobo.globo.com/capital/post/b2w-dona-dos-sites-americanas-esubmarino-coloca-tuk-tuks-eletricos-para-fazer-entregas.html>. Acesso em: 05 de abril de 2021.

SiMOES, C. P.; FERREIRA, G. S.; AFONSO, R. C. M.; BARTHOlO, R. Responsabilidade Social e Cidadania: Conceitos e Ferramentas. Brasília: Sesi - Departamento Nacional, 2008. 
STONE. Tudo começa com um propósito. Disponível em: <https://www.stone.com.br/porque-stone/>. Acesso em: 29 de março. 2021.

TIME STONE. Green Angels: Nossos guerreiros das soluções das ruas. Rio de Janeiro, 30 jan. 2018a. Disponível em: <https://jornadablog.stone.com.br/green-angels-guerreiros-das-ruas/>. Acesso em: 04 de maio. 2021.

TIME STONE. Um Green Day: conheça a rotina dos nossos Green Angels. Rio de Janeiro, 22 fev. 2018b. Disponível em: <https://jornadablog.stone.com.br/rotina-dos-green-angels/>. Acesso em: 04 de maio. 2021.

TIME STONE. Quer conhecer um time de elite? Vem conhecer a operação da Logística. Rio de Janeiro, 8 dez. 2017. Disponível em: <https://jornadablog.stone.com.br/vem-conhecer-operacao-da-logistica/>. Acesso em: 30 de maio. 2021

VERGARA, Sylvia Constant. Projetos e relatórios de pesquisa em administração. São Paulo: Atlas, 1998.

VICKERS, E. Economia Circular. Green Building Council Brasil, 27 ago. 2019. Disponível em: <https://www.gbcbrasil.org.br/economia-circular/>. Acesso em: 29 de maio. 2021. 